DIW BERLIN

Discussion

Papers

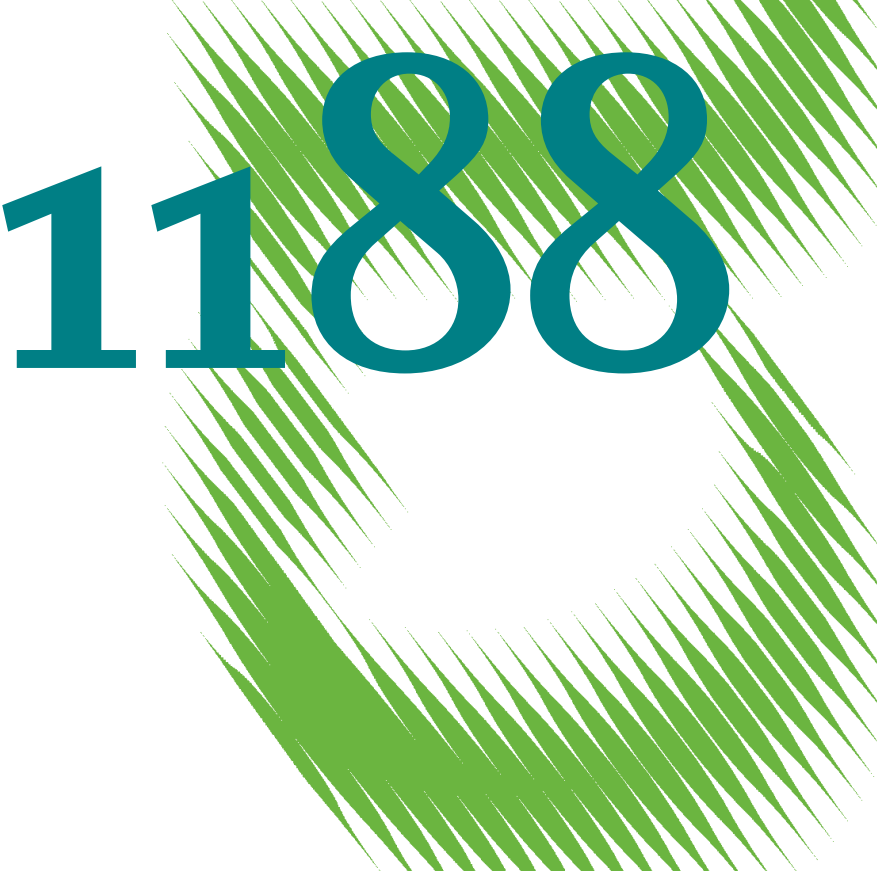

The Perfect Finance Minister

Whom to Appoint as Finance Minister

to Balance the Budget? 
Opinions expressed in this paper are those of the author(s) and do not necessarily reflect views of the institute.

IMPRESSUM

(C) DIW Berlin, 2012

DIW Berlin

German Institute for Economic Research

Mohrenstr. 58

10117 Berlin

Tel. $+49(30) 89789-0$

Fax +49 (30) $89789-200$

http://www.diw.de

ISSN print edition $1433-0210$

ISSN electronic edition 1619-4535

Papers can be downloaded free of charge from the DIW Berlin website:

http://www.diw.de/discussionpapers

Discussion Papers of DIW Berlin are indexed in RePEc and SSRN:

http://ideas.repec.org/s/diw/diwwpp.html

http://www.ssrn.com/link/DIW-Berlin-German-Inst-Econ-Res.html 


\title{
The perfect finance minister: Whom to appoint as finance minister to balance the budget?
}

\author{
Beate Jochimsen \\ Berlin School of Economics and Law \\ German Institute for Economic Research (DIW Berlin) \\ Sebastian Thomasius* \\ Free University of Berlin \\ Berlin School of Economics and Law \\ German Institute for Economic Research (DIW Berlin)
}

February 2012

\begin{abstract}
The role and influence of the finance minister within the cabinet are discussed with increasing prominence in the recent theoretical literature on the political economy of budget deficits. It is generally assumed that the spending ministers can raise their reputation purely with new or more extensive expenditure programs, whereas solely the finance minister is interested to balance the budget. Using a dynamic panel model to study the development of public deficits in the German states between 1960 and 2009, we identify several personal characteristics of the finance ministers that significantly influence budgetary performance. Namely her professional background seems to affect budget deficits. During times of fiscal stress, our results can guide prime ministers in the nominating of finance ministers in order to assure sound budgeting.
\end{abstract}

Keywords: fiscal policy, public deficit, political economy, finance minister

JEL classification: D78, H30, H74

${ }^{*}$ Corresponding author: Department of Economics, Free University of Berlin, Boltzmannstraße 20, 14195

Berlin, Germany; sebastian.thomasius@fu-berlin.de. 


\section{Introduction}

While a benevolent dictator or a welfare maximizing government would choose the optimal level of debt to finance public expenditures, in reality politicians face many incentives to leave the path of welfare maximizing indebtness; particularly as the optimal level of debt is not accurately measurable. The debt crisis in European countries and in the United States triggered a new debate on the reasons for excessive budget deficits and public debt. Besides general economic circumstances, much of the discussion focuses on the institutional and political factors that cause poor fiscal performance. Theories on political business cycles, partisan behavior, and weak governments try to explain the emergence of excessive deficits, e.g., (Alesina, Perotti, and Tavares, 1998; Persson and Tabellini, 1999 , Rogoff and Sibert, 1988; Alesina, 1988; Roubini and Sachs, 1989b).

Some researchers include the position of the minister of finance within the cabinet in their analysis. Compared to spending ministers representing only the interests of their own ministries, the finance minister is the most crucial cabinet member with respect to the deficit. She is the only minister with an overall responsibility for the budget. Therefore, the strength of the finance minister might have an influence on fiscal performance. As factors strengthening the minister of finance, the literature examines her procedural rights (Hagen and Harden, 1995; Hallerberg, Strauch, and Hagen, 2007), her relationship with the prime minister (Jochimsen and Nuscheler, 2011) and the number of spending ministers in opposition to her (Hagen and Harden, 1995: Kontopoulos and Perotti, 1999, Volkerink and Haan, 2001). Somewhat surprisingly, however, individual characteristics of the finance minister such as personal career planning, educational background and professional experience as well as gender and family status are unexplored.

This article is a first step to address this deficiency. With a new dataset that includes biographical information on the ministers of finance in German federal states, we test several hypotheses derived from existing theories on the political economy of budget deficits. The new dataset comprises information on the educational, the professional, and the political background as well as on gender and family status of all ministers of finance in former West German states from 1960 through 2009. We find that personal characteristics of finance ministers do influence fiscal performance. Our main finding is that the professional experience of the finance minister prior to her nomination affects public deficits. Finance ministers who gained financial expertise, e.g., in the financial business sector, achieve significantly lower deficits than all others. We do not find evidence that her education affects the deficit in any way. Apparently, it does not matter if the finance minister has a university degree or which subject she studied. Furthermore we find that neither the finance minister's gender nor her family status or her age affect public deficits. However, the strength of the finance minister within the cabinet increases with her tenure. The longer she is in office the lower are annual deficits. In coalition governments, the finance minister's position is even stronger if she and the prime minister belong to the same party. However, we do not find support for the partisan theory, i.e. politically left finance ministers do not incur higher deficits than politically right ones.

We employ various dynamic panel estimation methods and our main results are robust. Our findings are relevant for the design of democratic institutions, too. Perhaps the process of nomination of party candidates has to be reconsidered because professional experience is not the most important election criterion, so far. This opens up room for further analyses.

The article consists of six parts. The following second part briefly discusses the im- 
portance of political decision makers and describes related studies that use information about the individual background of (political) decision makers to explain policy outcomes in economic and monetary policy, changes in the form of government and corporate performance. The third part presents Germany's political and institutional background. In part four, we derive the hypotheses to be tested from a review of the literature focusing on the weak government hypothesis to explain fiscal performance. The fifth part introduces our dataset and, also, presents the estimation models and the results. The final part provides concluding remarks and some fiscal policy suggestions.

\section{Relevance of (political) decision makers}

Economic theory emphasizes the role of institutions and incentives for decision making or resulting economic outcomes. Studies analyzing the effects of political competition on the quality of politicians (e.g., Paola and Scoppa, 2011; Galasso and Nannicini, 2011) indicate that stronger political competition increases the quality of politicians in terms of their educational attainment and professional experience. Political decision makers themselves and their characteristics have received much less attention, however. It is rarely discussed what actually makes a politician competent $1^{1}$

Still, some economic scholars empirically study the influence of (political) decision makers' personal characteristics on their (business) performance. Thereby, four areas are addressed: (i) economic policy, (ii) monetary policy, (iii) changes in the form of government and (iv) corporate performance. In the following subsections, we briefly discuss related studies in these areas.

\subsection{Economic policy}

Only a few scholars have studied the influence of political decision makers on economic policy empirically ${ }^{2}$ Jones and Olken (2005), for example, discuss how the death of a political leader affects growth in 130 countries. They find a statistically significant effect of incidental leadership changes on growth - especially in autocratic countries. Persson and Zhuravskaya (2011) analyze the influence of the background of provincial leaders on local public policy in China. They find that politicians who built up their career within the region they govern provide more local public goods. Nevertheless, Jones and Olken (2005) as well as Persson and Zhuravskaya (2011) do not consider the individual characteristics - despite regional relatedness - of political leaders and therefore no conclusions can be drawn with respect to these characteristics.

Dreher et al. (2009) investigate the influence of the educational and professional background of the head of government on the implementation of market-liberalizing reforms. Their study provides empirical evidence for the relevance of the professional background, e.g., they find reforms to be more likely under a head of government who worked as an entrepreneur previously. Congleton and Zhang (2009) use a similar approach and analyze

\footnotetext{
${ }^{1}$ However, it is common to model two types of politicians (high or low levels of competence) when examining the strategies they adopt to increase their probability of (re-)election - we discuss such models in the chapter on the political economy of public deficits.

${ }^{2} \mathrm{~A}$ case study approach is used by Brady and Spence (2009) who study the impact of political leadership on economic growth for 13 countries with high rates of economic growth. However, it might be difficult to disentangle the different influencing factors when using such a case study approach.
} 
the influence of U.S. presidents on economic growth. Their results indicate that higher levels of education and specific professional experiences of a president substantially increase economic growth. The results of Dreher et al. and Congleton and Zhang are more robust for the professional experience than for the educational background.

Furthermore, some researchers concentrate on the impact of women on economic policy. In 2004 Chattopadhyay and Duflo (2004) analyze the influence of women representation in local councils in India on the types of locally provided public goods. They show that council members invest more in infrastructure that is directly related to the needs of their own gender. Similar results can be found in Svaleryd (2009). She studies whether women's representation in Swedish local councils affects local public expenditure structures. Her results show a positive relation between the share of women on local councils and the spending on childcare and education relative to elderly care.

\subsection{Monetary policy}

In the field of monetary policy, scholars discussed individual characteristics of decision makers already in the early 1990s. Of particular interest is how the voting behavior in the Federal Open Market Committee and the resulting U.S. inflation rate is affected by the educational and professional background of the committee's members (cf. Chappell, Havrilesky, and McGregor, 1995). In the first international study, Göhlmann and Vaubel (2007) find strong evidence that the inflation preferences of members of the central bank council depend on their education and professional experience. According to them, more law graduates in the council come along with higher inflation rates compared to economists while former members of the central bank staff are accompanied by significantly lower inflation rates than former politicians. Related studies by Farvaque, Hammadou, and Stanek (2009, 2011) support these results on the relevance of professional experience. Additionally, they find evidence that more women in the council reduces the inflation rate, a result that is statistically significant. Again and similar to economic policy, the results for education are less robust than for the professional experience.

\subsection{Changes in the form of government}

Another field of research where political decision makers are under consideration examines institutional and constitutional changes in the form of government. Jones and Olken (2009) investigate the effects of assassinations and assassination attempts against political leaders on the institutional setup within a country between 1875 and 2004. They find that a successful assassination of autocrats will significantly increase the likelihood of a transition to democracy thereafter. A related study by Hayo and Voigt (2011) yields similar results. Though the results of both Jones and Olken (2009) and Hayo and Voigt (2011) demonstrate that the circumstances under which the reign of political leaders is terminated matter for changes in the form of government, but their results do not indicate whether the individual characteristics of political leaders themselves are relevant for such changes.

\subsection{Corporate performance}

Other scholars investigate how the individual characteristics of decision makers affect corporate performance. Hau and Thum (2009), for example, study the influence of super- 
visory board members on the profitability of Germany's largest banks. They demonstrate that the underperformance of Germany's state-owned banks in the financial crisis can be traced to lower levels of 'boardroom competence' of their supervisory board members. They measure competence based on educational attainments and professional experience in business or finance and find the latter to be relevant, but not the former.

However, scholars in business and management have discussed the relevance of corporate decision makers like the CEO for profits or stock prices more often than economists. In an early study, Johnson et al. (1985) find evidence that stock price movements after the death of a senior corporate executive depend on the status of the executive who passed away. Bertrand and Schoar (2003) examine the impact of the CEO and show that her educational background, her age and her tenure are substantially relevant for several corporate decisions on investments, cash holdings or the debt leverage.

Several studies also take the gender of corporate decision makers into account. However, results are rather mixed. In their comprehensive study Dezsö and Ross (2008) show that companies with a higher share of women in the top management have a higher market valuation (measured by Tobin's Q), although they could not find a significant effect of the gender of the CEO herself. Their data set covered 1,500 large U.S. based companies between 1992 and 2006. Others, like Adams and Ferreira (2009), find a negative relation between the fraction of female directors and both the market valuation (Tobin's Q) and return on assets. Their unbalanced panel consisted of 2,000 U.S. based companies between 1996 and 20033

The studies in the areas economic policy, monetary policy, and corporate performance point out that decision makers and their personal characteristics matter for political and economic outcomes. The results also indicate a higher relevance of professional experience compared to educational attainment. Only the analyses on changes in the form of government do not find an influence of personal characteristics on the relevant outcome.

\section{Institutional setting}

\subsection{Germany's federal design and political parties}

The 'Federal Republic of Germany' (FRG) is a federal state consisting of three levels of government, namely the federal level (Bund), 16 states (Länder), and about 11,340 local authorities (Gemeinden). Germany has only had 16 states since 1990: 10 former West German states, five former East German states, and Berlin. Note that not all 10 West German states existed when the FRG was founded. Three southwestern states formed Baden-Württemberg after a merger in 1952. The Saarland joined the FRG in 1957, following a period of French administration. Therefore, we start our analysis in 1960. Furthermore, we follow the related literature and do not include Berlin and the five East German states. The time after the German reunification in 1990 is too short to provide a sufficient variation in the (political) variables of interest for the five East German states. The city state of Berlin is not included because Berlin was divided prior to reunification. While divided, the Eastern part was the capital of the GDR and the

\footnotetext{
${ }^{3}$ Both studies, Dezsö and Ross (2008) and Adams and Ferreira (2009), provide extensive literature reviews.
} 
Western part was affiliated with the FRG. Both parts received substantial funding from the respective central government, thus limiting the need to issue debt.

Before 1960, the party system was relatively unstable and several small regional parties were in government coalitions for a short period and, subsequently, disappeared or merged with other parties. Modern Germany has five major political parties. The Christian Democratic Union (CDU, i.e. centre-right) the Social Democratic Party (SPD, i.e. centre-left), the Free Democratic Party (FDP, i.e. liberal), the Green Party (I.E. ECOLOGICAL), and the Left Party (I.E. VERY LEFT WING). The first three have participated in elections since 1960. The Green Party was founded in 1980 and was first elected to state parliament in 1982 in Hamburg and Hesse; seats in the federal parliament followed in 1983. The Left Party appeared in 2007 after a merger of the Party of Democratic Socialism (PDS), the former East German communist party, with the Labour and Social Justice - The Electoral Alternative (WASG), a party formed by disappointed union members and former Social Democrats.

Since 1960, West German states have been governed either by a single party government, led by the CDU or SPD, or by coalitions typically consisting of two parties. Usually the CDU forms coalitions with the FDP or with the SPD, with the latter called 'grand coalitions'. Starting in 2008, the CDU forms coalitions with the Green Party (mid-2008 in Hamburg and at the end of 2009 in Saarland). The SPD governs with CDU ('grandcoalitions'), FDP, Green, and the Left Party. However, the latter coalition between SPD and the Left Party only exists in East Germany and Berlin and, therefore, does not appear in our analysis.

\subsection{Fiscal federalism in Germany}

The 16 states are endowed with their own powers including an autonomous budget. Although, the local authorities have the right to independently administer their own affairs, their fiscal independence is rather limited. Thus, due to the formal independence of the local authorities, state governments cannot be made responsible for narrowly limited local deficits. Therefore, it is logically consistent to concentrate on state deficits and neglect local deficits.

The fiscal federalism structure in Germany is dominated by joint taxes where tax revenue is shared across all three levels of government. Where the federal level has no restrictions concerning the design of its own taxes, sub-national governments have little power when it comes to setting taxes. States do not have any tax setting autonomy.5 The local level can raise some smaller taxes and can determine the tax rate for real estate tax and for business tax. Still, the federal and the state level negotiate the distribution of tax revenue out of joint taxes. As a consequence, citizens often have no idea which level of government is responsible for their tax burden. That makes it almost impossible for them to control their governments in this policy area and this might give politicians incentives to pursue fiscal policy in a suboptimal way.

Until the end of 2010, there were no restrictions for federal- and state-level debt issue.

\footnotetext{
${ }^{4}$ For historical reasons the CDU never runs for elections in Bavaria. Instead, their so-called sister party, the Christian Social Union (Csu), participates in elections. As both parties have similar programs and have always formed a parliamentary group in the federal parliament, we do not distinguish between them and label both CDU.

${ }^{5}$ Since 2006 there is one exemption. The rate of the property acquisition tax can be determined by the states from stage 1 of the federalism reforms.
} 
In the federal as well as in many state constitutions there was a formal requirement that a government's net borrowing should not exceed its planned investment expenditures. However, this requirement was linked to standard economic conditions, which lessened the strictness of the rule. As politicians face incentives to rise debt to a sub-optimal level, this golden rule was not successful in limiting indebtedness in Germany. With the European Economic and Monetary Union Germany faces additional restrictions for indebtedness. Still, the development since the introduction of the Euro shows that the economic sanctions for violating these criteria were not implemented. Since the beginning of 2011, Germany implemented completely new debt rules, namely a debt brake. It is far too early to evaluate this new setting.

Among the states there is a sophisticated fiscal equalization system in which financially strong states provide equalization payments to financially weak states. It ensures that all states have adequate financial resources to carry out their tasks and maintain their sovereignty. Aligning the revenue of the states is intended to create and maintain equal living conditions for the entire population of Germany. Between 1994 until 2004 two German states, Bremen and the Saarland, were bailed out by the federal government. This bailout reduced budget deficits in these states, but not to the anticipated degree. Furthermore, this federal bailout might have altered the incentives for all other states to issue debt. We account for these aspects in our analysis.

\section{Political economy of public deficits}

Public finance theories on budget deficits concentrate on partisan politics, political opportunism and weak governments. For the German states several empirical studies try to explain the development of state deficits using these theories (Seitz, 2000, Galli and Rossi, 2002, Jochimsen and Nuscheler, 2011). Therefore, we take variables based on these theoretical attempts as controls only.

Instead we focus on the role and characteristics of the finance minister. Traditional public finance theory assumes that all cabinet members have control over some part of the budget, but no member is responsible for the whole budget. In those settings sound public budgets have the same characteristics as public goods. A common pool problem emerges (Buchanan and Tullock, 1962, ch. 11) that could be overcome - or at least softened - by centralizing financial responsibility. If the budget is set up decentralized, spending ministers independently develop their expenditure plans. According to Hagen and Harden (1995), a suboptimally large budget then will result. Within the cabinet, the minister of finance is particularly important for fiscal performance because she is the only member of the cabinet - beside the prime minister - not promoting the interests of a spending ministry: She is assumed to be immune to the spending bias of her colleagues. Her political success comes along with a sound fiscal policy and only this policy will raise her prestige and, thereby, her re-nomination or re-election probability. Consequently, her interests regarding borrowing should be more in line with those of the average taxpayer (cf. Hagen and Harden, 1995; Hallerberg and Hagen, 1999; Feld and Schaltegger, 2010; Jochimsen and Nuscheler, 2011; Wehner, 2010). Therefore, we concentrate on a still unexplored aspect of the theory on weak governments, namely the position of the finance minister within the cabinet. 


\subsection{Personality of the finance minister}

The common view is that a strong minister of finance may resolve the common pool problem of weak governments by disciplining her minister colleagues. However, there is no common understanding of what makes a finance minister strong. Some contributions focus on the procedural rules of the finance minister in the budget process (e.g., Hagen and Harden, 1995; Hallerberg and Hagen, 1999; Hallerberg, Strauch, and Hagen, 2007). Yet, procedural rules are roughly identical in all German states. Other authors focus on tenure (Feld and Schaltegger, 2010) and party affiliation (Jochimsen and Nuscheler, 2011). We pick up those approaches and include them in this study.

Still, the personality of the finance minister and the relevance of her individual characteristics for fiscal performance are unexplored. Besley (2005, p. 58) argues that 'modern political economy has tended to focus only on the incentives faced by politicians for good or bad behavior, while neglecting the importance of selection. But no society can run effective public institutions while ignoring the quality of who is recruited to public office and what they stand for.' This article takes first steps in this direction.

\section{Authority, reputation, and time horizons}

Jochimsen and Nuscheler (2011) are the first to define 'strengths' of the finance minister in the context of an empirical study. They consider the finance minster to be in a strong position if she belongs to the party of the prime minister. This definition fits well to Hallerberg and Hagen (1999), who put forward that the finance minster can only set up the budget according to her and the taxpayers' preferences if she is supported by the prime minister. This backing is more likely to come if both the prime minister and the finance minister have the same party affiliation because then they will probably have more political views in common.

Hypothesis 1 If the finance minister and the prime minister belong to the same party in a coalition government the finance minster will be stronger and, therefore, the deficit will be lower than otherwise.

Following Barro s (1973) discussion on politician's time horizon and the potential "lame duck" effect, it is plausible that the time horizon of the finance minister affects fiscal policy and public debt. Tirole (1994) points out that career concerns are probably the main driver for politicians. In the absence of substantial monetary rewards (compared to the business sector), they are concerned with the effect of their current performance on their reputation and future career, i.e., re-election or career prospects in the private and public sector. Besley and Case (1995) expand this idea in their reputataion building model, in which the incentives for reputation building are weakened by shorter time horizons due to term limits. Basically, this describes the well known last period problem in a repeated game setting. Following Besley and Case (1995), finance ministers with a short time horizon, e.g., ministers close to retirement, may not be as effective as younger finance ministers.

Hypothesis 2 The closer the finance minister is to retirement the greater the deficit will be.

Feld and Schaltegger (2010) regard finance ministers with a greater tenure as indicator of government stability and argue that longer-tenured ministers of finance enjoy more 
authority and a politically powerful position towards the legislative, interest groups, and the other members of the cabinet, namely the spending ministers. Also Lott and Reed (1989) say that political markets sort out poorly performing politicians over time.

Hypothesis 3 The longer the tenure of the finance minister the stronger is her position in cabinet and the lower the deficit will be.

\section{Educational background and professional experiences}

It is a difficult task to measure the quality of politicians since there is not a single unquestionable indicator for politician quality. We will follow the related literature (e.g. Dreher et al., 2009, Göhlmann and Vaubel, 2007; Hau and Thum, 2009) and draw upon the human capital of politicians, which they acquired during their education and previous employment, in order to measure their quality (cf. Becker, 1993). The educational and the occupational background may affect the identity of the finance minister (in the sense of Akerlof and Kranton, 2005) and her attitude towards fiscal policy. Thus, the finance minister may act as partisan for her beliefs literally shaped by this formation professionnelle. One could expect that trained economists and business people may dislike deficit spending more than other people do.

If political competition is strong and commitment is binding, one might think that the background of politicians should not influence their decisions but rather that their positions converge $(\overline{\text { Frey, }}, 2000$, p. 20). However, there are limits to credible policy commitments. Consequently, we think that academic and professional qualification will matter.

Hypothesis 4 An education in economics or business and professional work experience in the finance sector will strengthen the finance minister and, consequently, lower budget deficits.

\section{Gender and family status}

Additionally, the gender of the finance minister might affect the deficit as well for possibly two reasons. First, several studies in behavioral economics find women to be more risk averse than men $\sqrt{6}$ However, other studies, focusing on managers and business professionals, could not find differences in financial risk preferences between men and women, once the financial and managerial knowledge is taken into account (Johnson and Powell, 1994 Atkinson, Baird, and Frye, 2003). Given the later results, we do not expect different deficits for female and male finance ministers. However, an alternative reason is that women and men may differ in terms of leadership effectiveness. Ministers in German state governments are predominantly male; the few female ministers usually head 'softer' ministries responsible for education, social or family policy (McKay, 2004). Sociologists have explained this underrepresentation of women in top-level positions with double standards for women and men (Foschi, 2000) and higher barriers for women to be appointed for a leadership position like the finance minister in our case (Lyness and Heilman, 2006) . $^{7}$ If a woman must be "twice as good as a man" in order to be appointed to a leadership

Eckel and Grossman (2008) and Croson and Gneezy (2009) offer two reviews of the economic literature on gender differences in risk preferences.

Reskin and Bielby (2005) review the literature on the underlying social differentiation process. 
position - like the finance minister - then women may be more effective leaders and superior performers compared to their male colleagues (Eagly, Karau, and Makhijani, 1995) 8 Therefore, female ministers of finance may incur lower deficits.

\section{Hypothesis 5 A female finance minister will have lower deficits than a male one.}

The family status of the finance minster can influence her attitude towards debt, too. If the finance minister has children one might assume that intergenerational equity is more important for her than otherwise. Because of an increased awareness of the implication of high public debt for future generations and of the importance of fiscal sustainability finance ministers with children should realize lower deficits(Barro, 1974).

\section{Hypothesis 6 Finance ministers with children will have lower deficits than others.}

Having deducted hypotheses on the impact of the finance minister's individual characteristics on public deficits, we regard it as necessary to discuss the potential issue of reverse causality. The electorate might choose specific politicians as an instrument to ensure the adoption of a specific policy and in the same way parties might use candidate nomination as a signal for their commitment to specific policies (Besley, 2005).9 Then, the selection of politicians would be endogenous. And indeed, some studies suggest that the qualification of politicians depends on the intensity of political competition. Paola and Scoppa (2011) show empirically that the qualification of local politicians in Italy increases with political competition. Galasso and Nannicini (2011) find a similar effect for the Italian parliament and furthermore show that politicians from opposing political coalitions - with different qualification levels on average - converge to high levels of qualification in highly contested electoral districts.

Besley (2005) discusses the self-selection of politicians as another source of endogeneity when he suggests that high opportunity costs make it unlikely that business people engage in politics in developed societies with a booming private sector. Gehlbach, Sonin, and Zhuravskaya (2010) have an even more pessimistic view. They take 'businessman candidacy' as an indicator for weak institutions and as a mean to avoid the cost of lobbying in immature democracies.

Even though we cannot rule out these possible reverse causalities completely, we do not regard these aspects as major issues here given the usual restrictions in the complex process of cabinet formation in the German states. The appointment of the finance minister and other cabinet members in the German states follows a different pattern. First, the number of potential candidates will usually be limited and will not cover the entire set of educational attainments and professional backgrounds. Second, the prime

\footnotetext{
${ }^{8}$ The psychologists refer to this as theory of a differential selection. However, Eagly, Karau, and Makhijani (1995) present three additional reasons for differences in leadership effectiveness between male and female leaders: (i) according to the social role theory women and men are (perceived as) most effective when they are engaged in activities consistent with their culturally defined gender roles; (ii) the organizational theory claims that only the formal role and organizational structure matter, so women and men are equally effective if they have the same status and power; and (iii) according to the contingency theory of leadership women and men differ in their leadership styles, while the effectiveness of any leader (female or male) depends on the specific circumstances and the appropriateness of her or his leadership style.

9 Besley (2005) discusses that the election of qualified politicians will improve government quality, in general, if ex post control through elections is limited. He considers mainly two dimensions of quality: honesty and competence.
} 
minister has to present a well-diversified and balanced cabinet to ensure the representation of all relevant groups, for example, varying regions, conflicting party wings, and different genders. Therefore, it is very unlikely that the education or the professional experience of the candidates will be the pivotal point in the selection process. ${ }^{10}$

Finally, it is worth mentioning that if such a reverse causality exists it would cause a positive relationship between the educational and professional attainment of the finance minister and the deficit. Economists or professionals with finance expertise would serve as finance ministers especially in times with high deficits. We expect the opposite relationship as stated in our hypotheses above.

\subsection{Traditional theories on budget deficits as control variables}

Following Downs (1957), the aim of an incumbent politician is to remain in office. In this case the objectives of all politicians become identical and party ideology does not matter any more. The resulting opportunistic behavior might cause political business cycles. Alesina, Perotti, and Tavares (1998), Persson and Tabellini (1999), Rogoff and Sibert (1988) and Rogoff (1990)discuss such political business cycles for fiscal policy. If there is a political business cycle in the German states deficits in pre-election or election years should differ significantly from those in all other years. ${ }^{11}$

In contrast to political opportunism, Kirschen et al. (1964, ch. IX) and Hibbs (1977) argue that economic policy outcomes are driven by government ideology. Ideologically motivated politicians want to win elections, too, but only in order to implement their desired policy. Left-wing politicians are expected to be more concerned with redistribution and to pursue more expansionary policies compared to right-wing politicians. As the German states cannot influence their tax revenue, expansionary spending programs will increase the deficit. Consequently deficits will be higher with politically left finance ministers.

Furthermore, weak governments might cause high deficits. According to Hagen and Harden (1995), fragmentation of government can be taken as an indicator for weakness. Government fragmentation increases with the number of coalition partners or with the overall number of ministers within a cabinet. Following the seminal contributions of Roubini and Sachs (1989ab), several empirical studies show that more fragmented governments are associated with higher government expenditures and larger deficits. ${ }^{12}$

\footnotetext{
${ }^{10}$ Dreher et al. (2009) argue similarly for the nomination of the head of government and show that the education and profession of politicians is clearly not affected by the state of the economy.

${ }^{11}$ Recently, Freier (2011) finds empirical evidence for the electoral advantages of incumbent parties at the local level in Germany.

${ }^{12}$ For example, the case of coalition governments is considered by Haan, Sturm, and Beekhuis $(1999)$, the case of large cabinets by Woo (2003) and Wehner (2010) while Volkerink and Haan (2001), Perotti and Kontopoulos (2002) and Schaltegger and Feld (2009) cover both aspects. Ashworth, Geys, and Heyndels (2005) and Wehner (2010) present extensive surveys of the empirical contributions on the common pool problem arising of political fragmentation. Persson and Tabellini (1999, section 6) offer an extensive survey of the literature on fragmentation over time and fragmented (coalition) governments as sources of political instability.
} 


\section{Empirical Analysis}

\subsection{Model specification}

In our analysis, we consider the deficit of the German states in real terms per capita as the most appropriate indicator of the finance minister's strength. In the empirical public finance literature, it is well established that in order to ensure stationary panels, the variable of interest, here the public deficit, must be transformed. Three concepts are principally used: First, growth rates; second, normalizing to a ratio of GDP; or, third, normalizing to per capita values. We follow the later and deflate the deficit data and normalize it with the state population for mainly three reasons. First, by using the deficit data we avoid comparing apples and oranges given the large differences of indebtedness between German states. Taking the debt level or its growth rate implicitly relates the performance of the finance minister to her predecessors within a state. ${ }^{13}$ Second, an interpretation of the deficit to GDP ratio might be misleading for the German states. The regional GDP differs largely between states and over time, but it has only limited impact on regional revenues as the equalization scheme levels out the differences between the states. Whereas business cycle related expenditures, like unemployment benefits, are not borne by the states (for a discussion of the expenditure structure of the states see Seitz, 2008). It is not the state level, but the local level that benefits from increases in regional GDP because local tax revenue remains to a far higher degree in the region than that of the state. Third, the equalization scheme allocates revenues to the states on a per capita basis and therefore the per capita normalization is most appropriate for state finances in Germany. After having examined its stationarity, the real deficit per capita is our variable of interest 14

The deficit in one period is not only influenced by current developments, but by past deficits, too. Therefore, we use a dynamic model in which we include the first lag of the dependent variable. Compared with other model specifications like a finite distributed lag or a model with an autoregressive error term, this specification assumes a geometrically declining influence of both the influencing factors and error terms of the past. ${ }^{15}$

Our dynamic model takes the following form:

\footnotetext{
${ }^{13}$ To illustrate this, compare two states with different levels of debt and assume both finance ministers to be equally strong and to realize the same deficit in absolute terms. Looking at the debt level or its growth rate, the finance minister of the more indebted state faces a lower relative number or growth rate and thereby appears stronger than the minister of the less indebted state. Whereas for two states with the same growth rates of debt, the finance minister of the less indebted state appears to perform better as the absolute deficit is lower.

${ }^{14}$ In accordance with our data set (large $T$ and small $N$ ), we use the Fisher-type unit-root test with the inverse Chi-square test statistic proposed by Choi $(2001)$. We could reject the null hypothesis that all states have a unit root in real per capita deficit for both specifications of this test, either based on augmented Dickey-Fuller (ADF) or Phillips-Perron (PP) unit-root tests. However, we had also to reject the null hypothesis of the Hadri LM test that the entire panel is stationary. Applying ADF tests for the 10 states separately, we identify the city state Bremen and the Saarland to have a unit root. This result is not surprising at all, since these states experienced severe deficits until they received additional fiscal transfers from the federal government between 1994 and 2004. During this bailout time, both states enjoyed a budget surplus and could reduce their debt level. However, after the end of the temporary transfers both states again had the highest per capita deficits. Thus, our test results probably arise from the bailout. As the time series of the remaining states are stationary, we use the real deficit per capita as our dependent variable and control for the bailout period.

${ }^{15}$ For a detailed discussion of different models see Beck and Katz $(2011)$.
} 


$$
\text { deficit }_{i, t}=\text { deficit }_{i, t-1}+x_{i, t}^{\prime} \beta_{1}+z_{i, t}^{\prime} \beta_{2}+\text { time }_{t}^{\prime} \beta_{3}+\mu_{i}+\epsilon_{i, t}
$$

in which deficit ${ }_{i, t}$ represents the real per capita public deficit in state $i=1, \ldots, N$ at time $t=1, \ldots, T$ and deficit $t_{i, t-1}$ its first lag. The vector $x_{i, t}$ comprises all variables referring to the finance minister. The economic and political control variables are summarized in vector $z_{i, t}$, both vectors are described in detail later on. We capture nation-wide fixed time effects with the vector time $e_{t}$. Finally, $\mu_{i}$ represents time-invariant state fixed effects. With respect to the error term we assume $\epsilon_{i, t}$ to be normally distributed and

$$
\begin{aligned}
E\left(\epsilon_{i, t} \epsilon_{j, s}\right) & =0 \text { for } i \neq j \text { or } t \neq s \\
E\left(\mu_{i} \epsilon_{j, s}\right) & =0 \text { for } \forall i, j \text { and } s \\
E\left(\left(x_{i, t}^{\prime} z_{i, t}^{\prime} t i m e_{t}^{\prime}\right) \epsilon_{j, s}\right) & =0 \text { for } \forall i, j, s \text { and } t
\end{aligned}
$$

\subsection{Description of our data set}

We compiled a unique data set comprising yearly data on political decision makers and public deficits for the 10 West German states. Given the observation period from 1960 to 2009 and one missing value for Saarland in 1960, we obtain an unbalanced panel with 499 observations in levels and 489 observations in differences.

We use data on credit market debt of the German states (within their core budget) and regional gross domestic product published by the German Federal Statistical Office. Deficits are calculated as debt changes. Both are deflated and normalized to real per capita terms using the consumer price index and regional population data (also published by the German Federal Statistical Office). Interest rate (discount rate) data is taken from Deutsche Bundesbank.

Furthermore, the data set captures the individual characteristics of all 110 finance ministers for the 10 West German states during the period under consideration. We compiled socio-demographic information of the finance ministers and their educational and occupational background based on the Munzinger biographical database (Internationales Biographisches Archiv) and other publicly available information (e.g., personal websites of politicians or government websites), Table 1 presents an overview. The State Chancelleries provided data on government (coalitions) and cabinet structure as well as election dates.

We took February 1st as cut-off date. Thus, the annual individual characteristics in our data set refer to the finance minister (or cabinet) who was in office on this day of the respective year. We chose this cut-off date as several states held regular elections in the last months of the year and quite often the newly formed government comes into office in January. This cut-off date allows us to consider the finance minister in office during the entire budgetary year and not the one who - by chance - stayed in office only until the end of January.

\section{Socio-demographic characteristics of the finance ministers}

The 110 finance ministers have a rather heterogeneous socio-demographic background. On average, they were appointed at the age of 51 while the earliest appointment was at the age of 34 , the latest at 67 . They were in office for an average of 3.5 years. While some ministers served only a few months, the finance minister with the longest tenure served for more than 16 consecutive years. On average the finance ministers had 2.5 children; 
one finance minister had 11 children. However, they were predominantly male with only seven female finance ministers, who collectively served for around 24 years and account for five percent of observations in our sample.

\section{Educational and occupational background of the finance ministers}

In our sample, all 110 finance ministers either passed the final secondary-education exam (the German 'Abitur') or a vocational training (apprenticeship). Three quarter of the ministers (83) earned a university degree (EDU_UNI) and, out of those, 41 added a PhD (31 percent, EDU_PHD). We use the remaining 27 ministers without a tertiary education as reference category. Most ministers who graduated from university studied law, namely 42 (LAW), 29 studied business or economics (ECONOMICS), nine humanities or other social sciences (Humanities) and four science or medicine (SCIENCE) ${ }^{16}$

Moreover, we coded the minister's work experience in different sectors prior to their appointment. Like the fields of study, the formed groups are not mutually exclusive. ${ }^{17}$ Not surprisingly, a majority of 88 out of 110 ministers were members of parliament (MP) prior to their appointment (in either the state parliament, the federal parliament or the parliament of the European Union). The second largest group with 68 ministers worked in the public sector (PUBLIC), thereof 60 in general public service (PUBLIC_other)and 15 in the field of public finances, e.g., tax authorities or treasury (PUBLIC_FINANCE). A total of 47 ministers gained professional experience in the business sector (BUSINESS), thereof 15 in the financial sector (BUSINESS_FINANCE) and 38 in other business sectors (BUSINESS_OTHER). In total, 40 finance ministers previously served as a spending minister. 11 ministers worked in academia (ACADEMIA), thereof six worked in economic or business research institutes or university departments. Seven were journalists, seven lawyers and three worked as party officers (OTHERs). Taking the finance related subsectors of academia, the business and public sector altogether, a total of 30 ministers gained financial expertise (FINANCE_EXPERTISE) ${ }^{18}$ We suppose that all the experiences that the finance ministers had over the course of their professional career are relevant for later performance.

\section{Position of the finance ministers}

We follow Jochimsen and Nuscheler (2011) and include a dummy variable for when the finance minister in a coalition government has strong ties with the prime minister as they both belong to the same party (AFFinity). Furthermore, we take into account the

\footnotetext{
${ }^{16}$ Note that some ministers studied multiple subjects. As we coded all subjects for them, simply counting the numbers of university degrees would give a wrong number of 84 university graduates instead of the correct 83

${ }^{17}$ In their related work on members of central banks' monetary policy committees Göhlmann and Vaubel (2007) and Farvaque, Hammadou, and Stanek (2009, 2011) only consider the dominant professional experience, i.e. the longest experience. We do not follow this approach and instead use all available information to fully capture the professional career prior to their appointment. Thus, the dummy variables covering the sectors mentioned above will assume the value of one if a finance minister has any experience in the respective sector. Therefore, these dummy variables are not mutually exclusive and for a minister who gained experience in three sectors for example the sum of these variables will be three compared to one following the approach of Göhlmann and Vaubel (2007) and Farvaque, Hammadou, and Stanek (2009, 2011).

${ }^{18}$ The variable FINANCE_EXPERTISE is a summary variable taking the value of one if a minister gained financial expertise in one or more of the academia, the business or public sector.
} 
political orientation of the finance minister with the dummy variable (LEFT) that takes the value of one if the finance minister belongs to the Social Democratic Party or the Green Party 19

\section{Economic and political control variables}

We control for the state of the economy by including the growth rate of regional gross domestic product in real terms per capita (GDP). As the deficit may depend on the cost of borrowing, we also include the real interest rate (INTEREST) that is the same for all states 20 At first glance, it may be plausible to include the level of state indebtedness as well. We refrain however to include any lagged debt level as this basically equals the cumulated deficits of the past. Recall that we already estimate a dynamic model by including the first lagged deficit.

Even though we have normalized both public deficit and GDP to per capita values, we include the regional population (POPULATION) as control variable to capture economies of scale in the provision of public goods ${ }^{21}$

Furthermore, we acknowledge the financial support that Bremen and the Saarland received from the federal government with a time dummy (BAILOUT) for both states during the respective years.

Additionally, we control for two effects described in the traditional political economy literature. First of all, we control for years with elections in the respective states (ELECTION) ${ }^{22}$ Furthermore, we account for the government fragmentation by including the probability that two randomly drawn ministers belong to different parties (FRACTION) as it is used, for example, in the well established World Bank Database on Political Institutions. In pure single-party governments this variable takes the value of zero while higher values indicate more fragmented governments in which ministers belong to different parties. Table 1 presents the descriptive statistics of the control variables as well. Definitions and sources of all variables can be found in table 6 in the appendix.

\subsection{Estimation methods}

Given our state-specific effects $\mu_{i}$ and the inclusion of a LDV in the regression, the Ordinary Least Squares (OLS) estimator is inconsistent. Specific panel-data estimators like the Fixed Effects (FE or Least Square Dummy Variable (LSDV)), and the Random Effects (RE or Generalized Least Square (GLS)) estimator wipe out the unobserved timeinvariant heterogeneity and thereby solve the omitted variable bias. However, they do not eliminate the LDV being correlated with the transformed error term (cf. Baltagi, 2008, ch.

\footnotetext{
${ }^{19}$ For a finance minister belonging to the Left Party, the dummy variable (LEFT) would take the value of one, too. However, the first finance minister belonging to the Left Party came into office in November 2009 and is not included in our data set as we restrict our analysis to the West German states between 1960 and 2009.

${ }^{20}$ We do not control for employment or unemployment levels due to the fact that labor market related expenditures are mainly born by the social security system and the local level.

${ }^{21}$ We expect states with a larger population to have lower per capita expenditures and therefore lower borrowing and vice-versa. Under the financial equalization scheme small states receive additional financial support for higher costs of political leadership.

${ }^{22}$ The ELECTION dummy variable is based on the same cut-off date that we use to identify the relevant finance minister for a respective year. However, for the coding of the ELECTION dummies it should not matter whether we use the January 1st, February 1st or March 1st. Out of 122 state elections in our sample only five took place in January and eight in February.
} 
Table 1: Descriptive statistics

\begin{tabular}{|c|c|c|c|c|c|c|}
\hline & \multicolumn{5}{|c|}{ All observations } & \multirow{2}{*}{$\begin{array}{c}\text { Out of } 110 \\
\text { ministers } \ldots \\
\text { with value }=1\end{array}$} \\
\hline & Obs. & Mean & Std. Dev. & Min & Max & \\
\hline \multirow[t]{2}{*}{ DEFICIT } & 499 & 167.996 & 263.213 & -852.894 & $1,552.622$ & - \\
\hline & \multicolumn{6}{|c|}{ Control variables } \\
\hline GDP & 499 & 2.240 & 3.243 & -6.717 & 13.556 & - \\
\hline INTEREST & 499 & 1.213 & 1.345 & -2.069 & 3.922 & - \\
\hline Population & 499 & 6.107 & 5.085 & 0.654 & 18.080 & - \\
\hline BAILOUT & 499 & 0.044 & 0.205 & 0 & 1 & - \\
\hline ELECTION & 499 & 0.240 & 0.428 & 0 & 1 & - \\
\hline \multirow[t]{2}{*}{ FRACTION } & 499 & 0.245 & 0.218 & 0 & 0.778 & - \\
\hline & \multicolumn{6}{|c|}{ Characteristics of Finance Ministers } \\
\hline AfFinity & 499 & 0.391 & 0.488 & 0 & 1 & - \\
\hline LEFT & 499 & 0.429 & 0.495 & 0 & 1 & 58 \\
\hline AGE & 499 & 54.467 & 6.412 & 34.717 & 70.617 & - \\
\hline AGESQ & 499 & $3,007.712$ & 705.185 & $1,205.279$ & $4,986.810$ & - \\
\hline TEnURE & 499 & 3.491 & 2.882 & 0.015 & 16.653 & - \\
\hline TEnuRESQ & 499 & 20.471 & 32.735 & 0.000 & 277.321 & - \\
\hline FEMALE & 499 & 0.046 & 0.210 & 0 & 1 & 7 \\
\hline KIDS & 499 & 0.768 & 0.423 & 0 & 1 & 87 \\
\hline \multirow[t]{2}{*}{ KIDS_N } & 499 & 2.465 & 2.146 & 0 & 11 & - \\
\hline & \multicolumn{6}{|c|}{ Education of Finance Ministers } \\
\hline EDU_UNI & 499 & 0.401 & 0.491 & 0 & 1 & 42 \\
\hline EDU_PHD & 499 & 0.315 & 0.465 & 0 & 1 & 41 \\
\hline ECONOMICS & 499 & 0.253 & 0.435 & 0 & 1 & 29 \\
\hline LAW & 499 & 0.381 & 0.486 & 0 & 1 & 42 \\
\hline HUMANITIES & 499 & 0.076 & 0.266 & 0 & 1 & 9 \\
\hline \multirow[t]{2}{*}{ SCIENCE } & 499 & 0.030 & 0.171 & 0 & 1 & 4 \\
\hline & \multicolumn{6}{|c|}{ Profession of Finance Ministers } \\
\hline FINANCE_EXPERTISE & 499 & 0.255 & 0.436 & 0 & 1 & 30 \\
\hline ACADEMIA & 499 & 0.078 & 0.269 & 0 & 1 & 11 \\
\hline ACADEMIA_FINANCE & 499 & 0.042 & 0.201 & 0 & 1 & 6 \\
\hline ACADEMIA_OTHER & 499 & 0.036 & 0.187 & 0 & 1 & 5 \\
\hline Business & 499 & 0.431 & 0.496 & 0 & 1 & 47 \\
\hline BUSINESS_FINANCE & 499 & 0.116 & 0.321 & 0 & 1 & 15 \\
\hline BUSINESS_OTHER & 499 & 0.375 & 0.485 & 0 & 1 & 38 \\
\hline MP & 499 & 0.796 & 0.404 & 0 & 1 & 88 \\
\hline SPENDING_MINISTER & 499 & 0.379 & 0.486 & 0 & 1 & 40 \\
\hline PuBliC & 499 & 0.631 & 0.483 & 0 & 1 & 68 \\
\hline PUBLIC_FINANCE & 499 & 0.142 & 0.350 & 0 & 1 & 15 \\
\hline PUbliC_other & 499 & 0.551 & 0.498 & 0 & 1 & 60 \\
\hline OTHER & 499 & 0.146 & 0.354 & 0 & 1 & 15 \\
\hline OTHER_JOURNALIST & 499 & 0.058 & 0.234 & 0 & 1 & 7 \\
\hline OTHER_LAWYER & 499 & 0.064 & 0.245 & 0 & 1 & 7 \\
\hline OTHER_PARTY & 499 & 0.030 & 0.171 & 0 & 1 & 3 \\
\hline
\end{tabular}

Note: All information refer to February 1st of the respective year, i.e., the cabinet or the finance ministers who were in office on February 1st. Table 6 in the appendix provides a detailled description of variables and data sources. 
8). According to Nickell (1981), the LSDV estimator is unbiased only as $T$ approaches infinity and generates severely biased coefficients for finite $T$, i.e., in short panels. He shows that $\hat{\gamma}$ is downward biased for $\gamma>0$ and the other coefficient estimates are upward biased if they are positively correlated with the LDV or vice-versa. ${ }^{23}$

Given our relatively long $(T=50)$, but small $(N=10)$ panel data set, one may argue that the bias of the LSDV estimator induced by the LDV is negligible. ${ }^{24}$ However, given the low number of 499 observations, we regard it as necessary to examine alternative estimation methods. Two general procedures are used to resolve the Nickell bias either by using instruments to obtain unbiased estimates or by directly correcting for it ${ }^{25}$

Following the first approach, the equation (1) is transformed to elminiate the timeinvariant effects, e.g., Anderson and Hsiao (1981, 1982, AH estimator) and Arellano and Bond (1991, AB estimator) propose using first-differences. Then instruments are used for the transformed LDV in order to eliminate the correlation with the transformed error term. Anderson and Hsiao (1981, 1982, AH estimator), for example, use further lags of the difference of the dependent variable $\Delta d_{i, t-2}=d_{i, t-2}-d_{i, t-3}$ or of its level $d_{i, t-2}$ as instruments for $\Delta d_{i, t-1}=d_{i, t-1}-d_{i, t-2}$. Whereas Arellano and Bond (1991) argue that there are more instruments available and propose a generalized method of moments (GMM) procedure. As the AB estimator exploits all valid lags of the dependent variable as instruments, it is more efficient than AH. Blundell and Bond (1998, BB estimator) suggest to use first-differenced instruments in the untransformed equation and instruments in levels for the first-differenced equation. However, the estimators discussed so far are well suited for large samples, but have poor finite sample properties and would generate biased estimates for small samples.

The second approach relies on the standard fixed-effects estimator (LSDV), but uses an approximation of its bias to obtain a bias-corrected estimator (LSDVc). ${ }^{26}$ The simulation studies of Judson and Owen (1999) and Bruno (2005a) as well as Kiviet and Bun (2001) and Bun and Kiviet (2006) show that the LSDVc estimator generates more accurate estimates and lower standard errors than the other estimators described above - particularly with long, but small panels. Given the properties of our data set $(T=50$ and $N=10)$, we employ the LSDVc estimator for our analysis.

The correction procedure of the LSDVc estimator requires an initial consistent estimate of the coefficients, which can be obtained using one of the mentioned $\mathrm{AB}, \mathrm{AH}$, or $\mathrm{BB}$ estimators. We use the $\mathrm{AB}$ estimator as it is more efficient than $\mathrm{AH}$ (Arellano and Bond, 1991) and appears to be more robust than BB (Bruno, 2005a). In accordance with the results of Bruno (2005a) and Bun and Kiviet (2003, 2006), we base the bias correction on the bias approximation in powers of $T^{-2} N^{-1}$. The simulation study of Kiviet and Bun (2001) demonstrates that the bootstrap procedure for the estimation of

\footnotetext{
$\sqrt[23]{\text { Nickell }}$ derives the approximation for the bias of $\hat{\gamma}$ for reasonably large values of $T$ and in the absence of exogenous regressors as $\operatorname{plim}_{N \rightarrow \infty}(\hat{\gamma}-\gamma) \approx \frac{-(1+\gamma)}{T-1}$. The bias of $\hat{\gamma}$ stays negative and becomes larger in absolute terms when exogenous regressors are included, but still approaches zero as $T$ becomes sufficiently large.

${ }^{24}$ And in fact using the approximation of Nickell (1981), the LSDV estimate $\hat{\gamma}$ might be downward biased by around six percent for a real $\gamma=0.5$ in a model without any other regressors.

${ }^{25}$ See Behr (2003) or Baltagi (2008, ch. 8) for a general discussion.

${ }^{26}$ Kiviet (1995) derives such an estimator by refining the bias approximation of Nickell (1981) in powers of $T^{-1}$, Bias approximations in powers of $(T N)^{-1}$ and $T^{-2} N^{-1}$ are suggested by Kiviet (1995, 1999). Simulation studies showed that the bias approximation in powers of $T^{-1}$ already accounts for more than 90 percent of the bias in balanced (Bun and Kiviet, 2003, 2006) and unbalanced panels (Bruno, 2005a).
} 
the variance-covariance matrix of the LSDVc estimator often outperforms the analytical variance estimator. We follow their suggestion and apply the bootstrap procedure for the standard errors with 200 repetitions.

Furthermore, we use the Arellano-Bond test on first-order autocorrelation of the residuals for all our regressions and - as expected - cannot reject the null hypothesis. However, there is no second-order autocorrelation in the residuals. We can clearly reject the null hypothesis of the Sargan test of over-identifying restrictions.

\subsection{Estimation results}

Table 2 and 3 illustrate the regression results. Before we turn to our hypotheses on the role of the finance minister, we briefly cover the base model in the first column of table 2 in which only the economic and political control variables are included.

The results indicate a rather strong path dependency of the deficit, as the estimated coefficient of the lagged deficit is positive, larger than 0.5 , and highly significant. The coefficient of GDP growth has a negative sign and is insignificant as expected. This supports our argument against the deficit to GDP ratio as dependent variable since state deficits and the regional GDP growth are only weakly related due to the fiscal equalization scheme and the fact that only a few business cycle related expenditures are at the state level. The coefficient for INTEREST has the expected negative sign, but is insignificant. The coefficient of the regional POPUlation has a negative sign and is highly significant indicating that states with more inhabitants have lower per capita deficits. Bremen and Saarland, for example, are not only the two smallest states, but also the two states with persistently high deficits. Two reasons might explain this result. First, there will be economies of scale in government structures favoring larger states. The fiscal equalization system addresses this with lump-sum transfers from the federal government to the smaller states. However, our results suggest that these transfers are not large enough. Second, wheeling and dealing might be more prevalent in smaller states.

During the federal government bailout for Bremen and the Saarland, both states significantly reduced their annual deficits by around EUR 248 per inhabitant (BAILOUT).

Both variables capturing the traditional political economy theory on political business cycles (ELECTION) and weak governments (FRACTION) are insignificant. while the former has the expected positive signs, the later has an unexpected negative sign. However, we find no support for significant differences in deficits neither in election years and nor for more fragmented governments.

\section{Authority, reputation, and time horizons}

Turning to the finance minister, model 2 includes her affiliation with the prime minister as well as her age. Our variable AfFinity for finance ministers belonging to the prime ministers party (in coalition governments only) has the expected negative sign and is significant at the $10 \%$ level. The variable FRACTION, capturing the government fragmentation, turns positive but remains insignificant. While the results of our base model indicate that more fragmented governments, i.e. coalition governments, do not have significantly higher deficits per se, model 2 shows that finance ministers can realize lower deficits in a coalition government if they belong to the party of the prime minister and, therefore, enjoy a greater authority within the cabinet. This results is in line with Jochimsen and Nuscheler (2011). Furthermore, we find no evidence for the partisan 
Table 2: Estimation results for age, tenure and education

\begin{tabular}{|c|c|c|c|c|c|c|}
\hline & \multicolumn{6}{|c|}{ Dependent variable: Deficit (real deficit per capita) } \\
\hline & (1) & $(2)$ & (3) & (4) & (5) & (6) \\
\hline L.DEFICIT & $\begin{array}{c}0.576^{* * *} \\
(0.045)\end{array}$ & $\begin{array}{c}0.563^{* * *} \\
(0.046)\end{array}$ & $\begin{array}{c}0.560^{* * *} \\
(0.046)\end{array}$ & $\begin{array}{c}0.558^{* * *} \\
(0.047)\end{array}$ & $\begin{array}{c}0.562^{* * *} \\
(0.046)\end{array}$ & $\begin{array}{c}0.565^{* * *} \\
(0.046)\end{array}$ \\
\hline GDP & $\begin{array}{l}-0.934 \\
(5.540)\end{array}$ & $\begin{array}{c}0.441 \\
(5.613)\end{array}$ & $\begin{array}{l}-0.666 \\
(5.589)\end{array}$ & $\begin{array}{l}-0.951 \\
(5.681)\end{array}$ & $\begin{array}{l}-0.665 \\
(5.595)\end{array}$ & $\begin{array}{l}-0.281 \\
(5.617)\end{array}$ \\
\hline INTEREST & $\begin{array}{c}-2.583 \\
(14.879)\end{array}$ & $\begin{array}{c}-6.861 \\
(14.783)\end{array}$ & $\begin{array}{c}-4.551 \\
(14.899)\end{array}$ & $\begin{array}{l}-4.200 \\
(14.998)\end{array}$ & $\begin{array}{l}-4.506 \\
(14.920)\end{array}$ & $\begin{array}{l}-5.145 \\
(15.050)\end{array}$ \\
\hline Population & $\begin{array}{c}-61.377^{* * *} \\
(22.249)\end{array}$ & $\begin{array}{c}-70.555^{* * *} \\
(24.596)\end{array}$ & $\begin{array}{c}-52.831^{* *} \\
(22.547)\end{array}$ & $\begin{array}{c}-53.041^{* *} \\
(22.541)\end{array}$ & $\begin{array}{c}-53.143^{* *} \\
(22.724)\end{array}$ & $\begin{array}{c}-54.533^{* *} \\
(23.226)\end{array}$ \\
\hline BAILOUT & $\begin{array}{l}-248.444^{* * *} \\
(47.294)\end{array}$ & $\begin{array}{l}-273.123^{* * *} \\
(47.636)\end{array}$ & $\begin{array}{l}-265.379 * * * \\
(48.257)\end{array}$ & $\begin{array}{l}-270.900^{* * *} \\
\quad(48.781)\end{array}$ & $\begin{array}{l}-264.890^{* * *} \\
(48.532)\end{array}$ & $\begin{array}{c}-266.687^{* * *} \\
(48.673)\end{array}$ \\
\hline ELECTION & $\begin{array}{c}17.482 \\
(17.293)\end{array}$ & $\begin{array}{c}17.241 \\
(17.254)\end{array}$ & $\begin{array}{c}14.908 \\
(17.439)\end{array}$ & $\begin{array}{c}14.260 \\
(17.434)\end{array}$ & $\begin{array}{c}14.962 \\
(17.457)\end{array}$ & $\begin{array}{c}15.362 \\
(17.454)\end{array}$ \\
\hline FraCtion & $\begin{array}{c}-2.587 \\
(40.323)\end{array}$ & $\begin{array}{c}63.206 \\
(57.895)\end{array}$ & $\begin{array}{c}58.310 \\
(57.458)\end{array}$ & $\begin{array}{c}62.082 \\
(57.608)\end{array}$ & $\begin{array}{c}58.754 \\
(57.592)\end{array}$ & $\begin{array}{c}52.212 \\
(56.949)\end{array}$ \\
\hline AfFinity & & $\begin{array}{l}-37.161^{*} \\
(21.755)\end{array}$ & $\begin{array}{l}-35.895 \\
(22.053)\end{array}$ & $\begin{array}{l}-39.307^{*} \\
(22.263)\end{array}$ & $\begin{array}{l}-36.256 \\
(22.213)\end{array}$ & $\begin{array}{l}-34.404 \\
(21.951)\end{array}$ \\
\hline LEFT & & $\begin{array}{c}8.287 \\
(21.153)\end{array}$ & $\begin{array}{l}15.086 \\
(21.379)\end{array}$ & $\begin{array}{l}14.239 \\
(21.411)\end{array}$ & $\begin{array}{l}14.816 \\
(21.439)\end{array}$ & $\begin{array}{l}10.963 \\
(21.690)\end{array}$ \\
\hline $\mathrm{AGE}$ & & $\begin{array}{l}-20.978 \\
(19.375)\end{array}$ & & & & \\
\hline AGESQ & & $\begin{array}{l}0.208 \\
(0.177)\end{array}$ & & & & \\
\hline Tenure & & & $\begin{array}{l}10.856 \\
(7.494)\end{array}$ & $\begin{array}{c}9.763 \\
(7.466)\end{array}$ & $\begin{array}{l}10.843 \\
(7.503)\end{array}$ & $\begin{array}{l}10.412 \\
(7.510)\end{array}$ \\
\hline Tenuresq & & & $\begin{array}{l}-1.181^{*} \\
(0.649)\end{array}$ & $\begin{array}{l}-1.135^{*} \\
(0.646)\end{array}$ & $\begin{array}{l}-1.176^{*} \\
(0.648)\end{array}$ & $\begin{array}{l}-1.148^{*} \\
(0.650)\end{array}$ \\
\hline EDU_UNI & & & & $\begin{array}{c}-8.438 \\
(19.603)\end{array}$ & & \\
\hline EDU_PHD & & & & $\begin{array}{l}-28.418 \\
(21.661)\end{array}$ & & \\
\hline ECONOMICS & & & & & $\begin{array}{c}3.030 \\
(20.281)\end{array}$ & $\begin{array}{l}-3.329 \\
(23.144)\end{array}$ \\
\hline LAW & & & & & & $\begin{array}{l}-6.900 \\
(19.160)\end{array}$ \\
\hline Humanities & & & & & & $\begin{array}{c}-5.901 \\
(35.623)\end{array}$ \\
\hline SCIENCE & & & & & & $\begin{array}{l}-49.172 \\
(48.369)\end{array}$ \\
\hline Observations & 489 & 489 & 489 & 489 & 489 & 489 \\
\hline Number of states & 10 & 10 & 10 & 10 & 10 & 10 \\
\hline
\end{tabular}

Notes: The LSDVc estimator was applied with an initial Arellano-Bond estimate and 200 bootstrap repetitions. The estimates include both year dummy (time fixed effects) and state dummy (country fixed effects) variables that are not shown here.

*** indicates significance at $1 \%$ level, ${ }^{* *}$ at $5 \%$ level and * at $10 \%$ level respectively. Standard errors are reported in parentheses.

theory. Finance ministers belonging to the Social Democratic Party or the Green Party (LEFT) do not exhibit significantly higher deficits. This result is consistent with most of the related studies on public finances in the German states that could not find partisan effects for overall spending or deficit (e.g., Seitz, 2000, Galli and Rossi, 2002, Jochimsen and Nuscheler, 2011). However, some more recent studies reveal that politicians act as partisans by changing the budget composition according to their ideological priorities, thereby leaving the deficit unaffected (e.g., Potrafke, 2010; Schneider, 2010).

The age of the finance minister, however, is not significant, neither the linear nor the quadratic term (AgE, AGESQ). Since age varies largely widely across the 110 finance ministers, we include the tenure instead of the age of the finance minister in model 3 to acknowledge the experience gained in office and find longer-tenured finance ministers 
to issue significantly less new debt than the newly appointed. The linear term TenuRE has a positive sign, but is not significant while the quadratic term TENURESQ is negative and significant. ${ }^{27}$ This confirms the results of Feld and Schaltegger (2010) and indicates that newly appointed ministers need some time to build up experience and to use their authority within the cabinet to lower the deficit.

\section{Educational background and professional experiences}

We find no evidence that the educational background of the finance minister affects public deficits. All educational variables are statistically insignificant - both with respect to the highest educational level attained (model 4) and the field of studies (models 5 and 6). We also could not reject the test on joint significance of theses variables in both estimations. The results are reported in table 2 .

Turning to the professional experience of the finance minister, we first consider only our six main categories covering the previous profession of the finance minister in model 7: Academia, Business, Mp (members of parliament), Spending_minister, Public, OTHER. No category is significant at the 10 percent level.

Model 8 examines the effect of the finance ministers' financial expertise in distinguishing categories and yields the expected result that finance ministers with working experience in the financial business sector (BUSINESS_FINANCE) can reduce the public deficit (at the 1 percent significance level). However, the working experience in the non-finance business sector (BUSINESS_OTHER) increases public deficits significantly. Former member of parliaments (MP) also incur lower deficits. All other sub-categories are insignificant.

As we are especially interested in the overall financial expertise gained by the finance minister prior her appointment, the summary variable FINANCIAL_EXPERTISE is included in model 9 to capture all finance-related work experience in either the financial business sector, public finances or as professors in business or economics: As expected the variable has a negative sign and is highly significant indicating that finance ministers with high levels of financial expertise can realize lower deficits. In model 10, we have decomposed the category ОтнеR, however, none of its three subcategories is significant.

Overall, we find no evidence for her education affecting the deficit. However, we find that professional experience in the financial field prior to appointment significantly reduces state deficits. Our findings are in line with results from studies in monetary and economic policy (e.g., Dreher et al., 2009, Farvaque, Hammadou, and Stanek, 2009, Hau and Thum, 2009) that show professional experience to be more influential than the educational background. Remember that we do not expect reverse causality to be of major importance here. Moreover such a reverse causality would yield a positive coefficient or at least cause an upward-biased estimate, while we observe a significant negative coefficient of the variable FINANCE_EXPERIENCE, as expected.

\section{Gender and family status}

Turning to gender and family status of the finance minister in model 11, one can see that these two individual characteristics clearly do not affect public deficit. Female ministers do not incur significantly higher deficits than their male colleagues. Furthermore, we find no evidence that finance ministers with children incur significantly lower deficits than

\footnotetext{
${ }^{27}$ Given the coefficients of the linear and the quadratic effect in model 3, we observe a turning point for tenure around 4.6 years. Ministers with a higher tenure incur significantly lower deficits.
} 
Table 3: Estimation results for professional experience, gender and family status

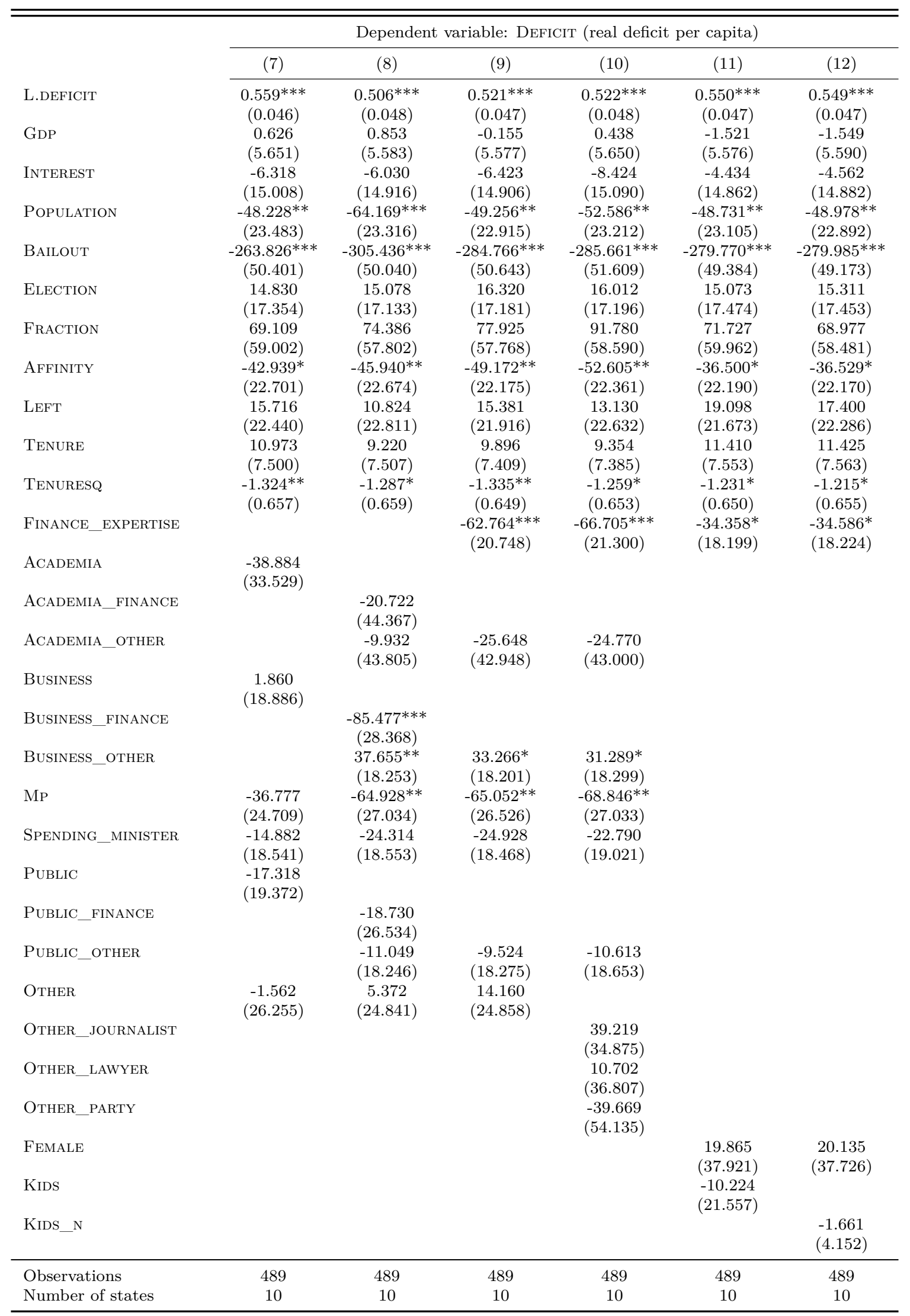

Notes: The LSDVc estimator was applied with an initial Arellano-Bond estimate and 200 bootstrap repetitions. The estimates include both year dummy (time fixed effects) and state dummy (country fixed effects) variables that are not shown here.

$* * *$ indicates significance at $1 \%$ level, $* *$ at $5 \%$ level and $*$ at $10 \%$ level respectively. Standard errors are reported in parentheses. 
ministers without. Also the number of children has no statistically significant effect on public deficits (model 12).

\subsection{Robustness checks}

We test the robustness of our results in several ways. First of all, we test alternative cut-off dates instead of our chosen cut-off date February 1st. We obtained similar results for the Tenure/TEnuresQ and the FinAncial_EXPERTiSe variables for various cutoff dates during the first half of a year (see table 4). Furthermore, we have implemented two alternative specifications to capture time effects. The two estimations without any time effects and with dummy variables for specific event: ${ }^{28}$, respectively, yield similar results in size and significance for the variable FinANCE_EXPERTISE and TENuRESQ. The Election dummy variable became significant as well (see table 5).

Additionally, we control for the robustness of our results with respect to alternative estimators like pooled OLS, the fixed effects estimator (LSDV) and the Arellano-Bond estimator. Rerunning the regressions, we find that our main results are robust to these alternatives ${ }^{29}$ It is not surprising that the significance of the FINANCE_EXPERTISE variable vanishes with a p-value of $13.3 \%$ for the pooled OLS estimation since no state fixed effects are included here. However, its coefficient is rather robust and the variable TEnURESQ stays significant with a p-value of $7.2 \%$. However, the pooled OLS estimates are inconsistent due to the lagged dependent variable and the unobserved state-specific effects (see above). We use the same specifications for the fixed effects (LSDV) and the Arellano-Bond estimator as for the LSDVc estimator before and can replicate our results with both alternative estimators for most of the specifications (see table 5). We also challenge our implementation of the LSDVc estimator and used an alternative initial estimator (BB) (cf. Kiviet and Bun, 2001, Bruno, 2005b). Our results remain the same. ${ }^{30}$

\section{Concluding remarks}

Although there is a large theoretical and an increasing empirical literature on the political economy of public deficits, the role and responsibility of the finance minister is so far neglected. This is particularly astonishing because in other policy areas, like economic policy, monetary policy, or corporate performance, the influence of individual characteristics on outcome and performance is already partly explored. By empirically analyzing the influence of the finance minister and her individual characteristics on public deficits in 10 West German states from 1960 to 2009, we try to overcome this shortcoming in public finance.

Using a new and unique dataset that includes the personal characteristics of all 110 relevant finance ministers, we employ several panel estimation techniques and report the following findings: There is strong evidence that the professional experience of the finance

\footnotetext{
${ }^{28}$ Specifically, we use time dummies for both the first and second oil crises and the financial crisis (OIL1, OIL2, Fin_CRISIS), for years after the German reunification (REunification) and the inclusion of the East German states into the fiscal equalization scheme (EQUALIZATION). We also included a time dummy for the period of the federal government's bailout for Bremen and Saarland to control for potential indirect effects on all states (BAILOUT__PERIOD).

${ }^{29}$ The estimated coefficient for the lagged deficit is higher with pooled OLS and lower with the fixed effects estimator than with LSDVc as discussed above.

${ }^{30}$ Results are available upon request.
} 
Table 4: Robustness checks for alternative cut-off dates

\begin{tabular}{|c|c|c|c|c|c|}
\hline & \multirow{2}{*}{$\frac{\text { Cut-off date }}{\text { February 1st }}$} & \multicolumn{4}{|c|}{ Alternative cut-off dates } \\
\hline & & January 1st & April 1st & July 1 st & October 1st \\
\hline & \multicolumn{5}{|c|}{ Dependent variable: DEFICIT (real deficit per capita) } \\
\hline L.DEFICIT & $\begin{array}{c}0.546^{* * *} \\
(0.046)\end{array}$ & $\begin{array}{c}0.549^{* * *} \\
(0.046)\end{array}$ & $\begin{array}{c}0.546^{* * *} \\
(0.046)\end{array}$ & $\begin{array}{c}0.542^{* * *} \\
(0.046)\end{array}$ & $\begin{array}{c}0.542^{* * *} \\
(0.046)\end{array}$ \\
\hline GDP & $\begin{array}{l}-1.408 \\
(5.551)\end{array}$ & $\begin{array}{l}-1.401 \\
(5.536)\end{array}$ & $\begin{array}{l}-1.050 \\
(5.546)\end{array}$ & $\begin{array}{l}-0.654 \\
(5.509)\end{array}$ & $\begin{array}{l}-0.536 \\
(5.481)\end{array}$ \\
\hline INTEREST & $\begin{array}{c}-4.944 \\
(14.865)\end{array}$ & $\begin{array}{c}-4.600 \\
(14.861)\end{array}$ & $\begin{array}{c}-4.984 \\
(14.858)\end{array}$ & $\begin{array}{c}-4.197 \\
(14.840)\end{array}$ & $\begin{array}{c}-3.216 \\
(14.889)\end{array}$ \\
\hline Population & $\begin{array}{c}-48.677^{* *} \\
(22.525)\end{array}$ & $\begin{array}{c}-48.656^{* *} \\
(22.595)\end{array}$ & $\begin{array}{c}-48.093^{* *} \\
(22.560)\end{array}$ & $\begin{array}{c}-47.440 * * \\
(22.460)\end{array}$ & $\begin{array}{c}-48.707^{* *} \\
(22.529)\end{array}$ \\
\hline BAILOUT & $\begin{array}{c}-276.915^{* * *} \\
(48.795)\end{array}$ & $\begin{array}{c}-273.183^{* * *} \\
(48.641)\end{array}$ & $\begin{array}{c}-277.698^{* * *} \\
(48.840)\end{array}$ & $\begin{array}{c}-277.778^{* * *} \\
(49.159)\end{array}$ & $\begin{array}{c}-283.121^{* * *} \\
(50.193)\end{array}$ \\
\hline ELECTION & $\begin{array}{c}14.845 \\
(17.374)\end{array}$ & $\begin{array}{c}12.094 \\
(16.823)\end{array}$ & $\begin{array}{c}7.325 \\
(17.248)\end{array}$ & $\begin{array}{c}1.913 \\
(17.016)\end{array}$ & $\begin{array}{c}-1.422 \\
(17.689)\end{array}$ \\
\hline FRACTION & $\begin{array}{c}66.780 \\
(57.491)\end{array}$ & $\begin{array}{c}64.360 \\
(56.605)\end{array}$ & $\begin{array}{c}66.825 \\
(57.649)\end{array}$ & $\begin{array}{c}96.632 \\
(60.740)\end{array}$ & $\begin{array}{l}103.636^{*} \\
(60.636)\end{array}$ \\
\hline AfFinity & $\begin{array}{l}-35.819 \\
(22.000)\end{array}$ & $\begin{array}{c}-36.776^{*} \\
(21.512)\end{array}$ & $\begin{array}{c}-37.642^{*} \\
(22.327)\end{array}$ & $\begin{array}{c}-50.786^{* *} \\
(22.494)\end{array}$ & $\begin{array}{c}-52.607^{* *} \\
(22.262)\end{array}$ \\
\hline LEFT & $\begin{array}{c}21.076 \\
(21.368)\end{array}$ & $\begin{array}{c}20.154 \\
(21.258)\end{array}$ & $\begin{array}{c}21.342 \\
(21.803)\end{array}$ & $\begin{array}{l}37.212^{*} \\
(21.637)\end{array}$ & $\begin{array}{c}34.794 \\
(21.756)\end{array}$ \\
\hline TENURE & $\begin{array}{c}11.266 \\
(7.470)\end{array}$ & $\begin{array}{c}12.178 \\
(7.480)\end{array}$ & $\begin{array}{l}12.900^{*} \\
(7.446)\end{array}$ & $\begin{array}{c}5.920 \\
(7.196)\end{array}$ & $\begin{array}{l}-1.960 \\
(7.400)\end{array}$ \\
\hline TEnuresQ & $\begin{array}{c}-1.217^{*} \\
(0.647)\end{array}$ & $\begin{array}{c}-1.269^{*} \\
(0.652)\end{array}$ & $\begin{array}{c}-1.268^{* *} \\
(0.643)\end{array}$ & $\begin{array}{l}-0.745 \\
(0.691)\end{array}$ & $\begin{array}{l}-0.115 \\
(0.687)\end{array}$ \\
\hline FINANCE_EXPERTISE & $\begin{array}{c}-35.681^{* *} \\
(17.933) \\
\end{array}$ & $\begin{array}{c}-31.384^{*} \\
(17.959)\end{array}$ & $\begin{array}{c}-35.272^{* *} \\
(17.516) \\
\end{array}$ & $\begin{array}{c}-35.315^{* *} \\
(16.654)\end{array}$ & $\begin{array}{c}-38.505^{* *} \\
(17.430)\end{array}$ \\
\hline Observations & 489 & 489 & 489 & 489 & 489 \\
\hline Number of states & 10 & 10 & 10 & 10 & 10 \\
\hline
\end{tabular}

Notes: The LSDVc estimator was applied with an initial Arellano-Bond estimate and 200 bootstrap repetitions. The estimates include both year dummy (time fixed effects) and state dummy (country fixed effects) variables that are not shown here.

*** indicates significance at $1 \%$ level, ${ }^{* *}$ at $5 \%$ level and $*$ at $10 \%$ level respectively. Standard errors are reported in parentheses.

minister prior to her nomination affects public deficits. Finance ministers who gained financial expertise, e.g., in the financial business sector, prior to their appointment achieve significantly lower deficits than all others. Furthermore, the finance minister's strength within the cabinet increases with her tenure. If she is more that 4.6 years in office annual deficits decrease significantly. In coalition governments, the finance minister's position is further strengthened if she and the prime minister belong to the same party.

We do not find evidence that her education affects the deficit in any way. Apparently it does not matter if the finance minister has a university degree or which subject she studied. Our findings correspond with results from studies in monetary and economic policy showing professional experience to be more influential than the educational background, too. Also gender and family status of finance ministers do not affect public deficits. Female ministers do no issue more or less debt than their male colleagues. Children do not affect the attitude towards debt either. Moreover, we find no evidence for the lame duck argument as the age of the finance minister is irrelevant for public deficits. Finally, there 


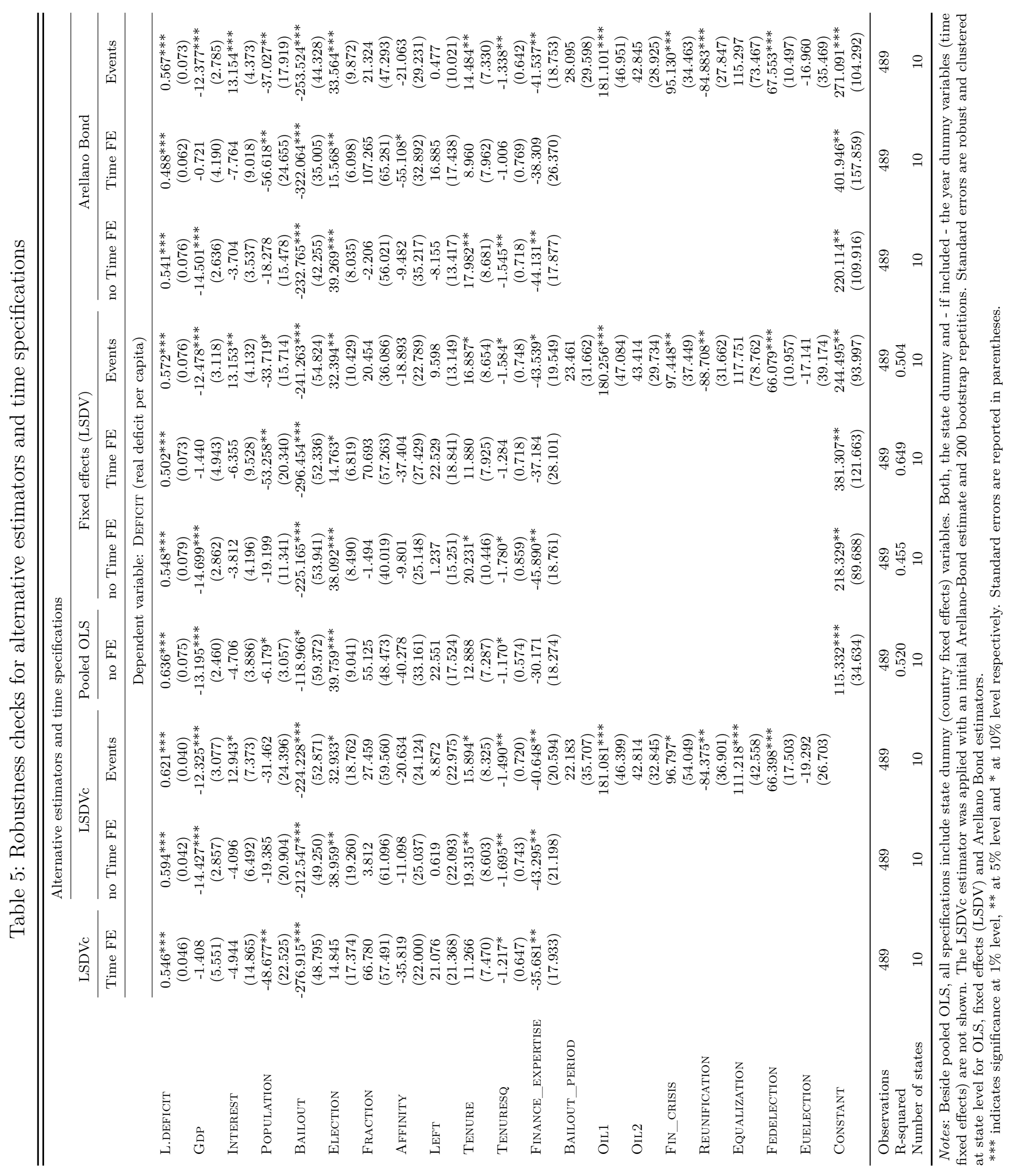


is no support for the partisan theory, i.e. politically left finance ministers do not incur higher deficits than politically right ones.

So what appear to be the characteristics of the 'perfect finance minister'? In times of fiscal stress and global fiscal uncertainties the 'perfect' finance minister should pay much attention to reaching a sound budget. It is more likely that she succeeds in doing so, if she has significant professional experience in the field of business finance and if she stays in office for a long time. Moreover, in a coalition government she should belong to the same party than the prime minister. It does not matter how old she is, or what (or if) she studied, or, for that matter whether the finance minister is male or female, with or without children.

Acknowledgments: We would like to thank Ronny Freier, Benny Geys and Marcel Thum as well as Monica Auteri and participants at the 2011 conference "New Perspectives on Public Debt" of the European Center for the Study of Public Choice in Rome and participants at seminars at Free University of Berlin, Technical University of Dresden and the 10th Public Finance Workshop at WZB Berlin. Comments of colleagues at Berlin School of Economics and Law, DIW Berlin and Free University of Berlin are also gratefully acknowledged. The usual disclaimer applies.

\section{References}

Adams, Renée B. and Daniel Ferreira. 2009. "Women in the boardroom and their impact on governance and performance." Journal of Financial Economics 94 (2):291-309.

Akerlof, George A. and Rachel E. Kranton. 2005. "Identity and the Economics of Organizations." The Journal of Economic Perspectives 19 (1):9-32.

Alesina, Alberto. 1988. "Macroeconomics and Politics." In NBER macroeconomics annual, vol. 3, edited by Stanley Fischer. Cambridge and Mass.: MIT Press, 13-62.

Alesina, Alberto, Roberto Perotti, and José Tavares. 1998. "The Political Economy of Fiscal Adjustments." Brookings Papers on Economic Activity 1998 (1):197-266.

Anderson, T. W. and Cheng Hsiao. 1981. "Estimation of Dynamic Models with Error Components." Journal of the American Statistical Association 76 (375):598-606.

1982. "Formulation and estimation of dynamic models using panel data." Journal of Econometrics 18 (1):47-82.

Arellano, Manuel and Stephen Bond. 1991. "Some Tests of Specification for Panel Data: Monte Carlo Evidence and an Application to Employment Equations." The Review of Economic Studies 58 (2):277.

Ashworth, John, Benny Geys, and Bruno Heyndels. 2005. "Government Weakness and Local Public Debt Development in Flemish Municipalities." International Tax and Public Finance 12 (4):395-422. 
Atkinson, Stanley M., Samantha Boyce Baird, and Melissa B. Frye. 2003. "Do Female Mutual Fund Managers Manage Differently?" Journal of Financial Research 26 (1):118.

Baltagi, Badi H. 2008. Econometric analysis of panel data. Chichester: John Wiley, 4 ed.

Barro, Robert J. 1973. "The control of politicians: An economic model." Public Choice $14(1): 19-42$.

. 1974. "Are Government Bonds Net Wealth?" Journal of Political Economy $82(6): 1095-1117$.

Beck, Nathaniel and Jonathan N. Katz. 2011. "Modeling Dynamics in Time-Series-CrossSection Political Economy Data." Annual Review of Political Science 14 (1):331-352.

Beck, Thorsten, George Clarke, Alberto Groff, Philip Keefer, and Patrick Walsh. 2001. "New tools in comparative political economy: The Database of Political Institutions." World Bank Economic Review 15 (1):165-176.

Becker, Gary S. 1993. Human capital: A theoretical and empirical analysis, with special reference to education. Chicago: University of Chicago Press, 3 ed.

Behr, Andreas. 2003. "A comparison of dynamic panel data estimators: Monte Carlo evidence and an application to the investment function." Discussion paper, Economic Research Centre of the Deutsche Bundesbank 5.

Bertrand, Marianne and Antoinette Schoar. 2003. "Managing with Style: The Effect of Managers on Firm Policies." The Quarterly Journal of Economics 118 (4):1169-1208.

Besley, Timothy. 2005. "Political Selection." The Journal of Economic Perspectives 19 (3):43-60.

Besley, Timothy and Anne Case. 1995. "Does Electoral Accountability Affect Economic Policy Choices? Evidence from Gubernatorial Term Limits." The Quarterly Journal of Economics 110 (3):769-798.

Blundell, Richard and Stephen Bond. 1998. "Initial conditions and moment restrictions in dynamic panel data models." Journal of Econometrics 87 (1):115-143.

Brady, David and Michael Spence. 2009. "Leadership and politics: a perspective from the Growth Commission." Oxford Review of Economic Policy 25 (2):205-218.

Bruno, Giovanni S.F. 2005a. "Approximating the bias of the LSDV estimator for dynamic unbalanced panel data models." Economics Letters 87 (3):361-366.

2005b. "Estimation and inference in dynamic unbalanced panel-data models with a small number of individuals." Stata Journal 5 (4):473-500.

Buchanan, James M. and Gordon Tullock. 1962. The calculus of consent. Ann Arbor: University of Michigan Press.

Bun, Maurice J. G. and Jan F. Kiviet. 2003. "On the diminishing returns of higher-order terms in asymptotic expansions of bias." Economics Letters 79 (2):145-152. 
2006. "The effects of dynamic feedbacks on LS and MM estimator accuracy in panel data models." Journal of Econometrics 132 (2):409-444.

Chappell, Henry W., Thomas M. Havrilesky, and Rob Roy McGregor. 1995. "Policymakers, institutions, and central bank decisions." Journal of Economics and Business 47 (2):113-136.

Chattopadhyay, Raghabendra and Esther Duflo. 2004. "Women as Policy Makers: Evidence from a Randomized Policy Experiment in India." Econometrica 72 (5):1409-1443.

Choi, In. 2001. "Unit root tests for panel data." Journal of International Money and Finance 20 (2):249-272.

Congleton, Roger D. and Yongjing Zhang. 2009. "Is it All About Competence? The Human Capital of U.S. Presidents and Economic Performance." SSRN eLibrary .

Croson, Rachel and Uri Gneezy. 2009. "Gender Differences in Preferences." Journal of Economic Literature 47 (2):448-474.

Dezsö, Cristian L. and David G. Ross. 2008. "'Girl Power': Female Participation in Top Management and Firm Performance." Working Paper, Columbia Business School August 2008.

Downs, Anthony. 1957. "An Economic Theory of Political Action in a Democracy." The Journal of Political Economy 65 (2):135-150.

Dreher, Axel, Michael J. Lamla, Sarah M. Lein, and Frank Somogyi. 2009. "The impact of political leaders' profession and education on reforms." Journal of Comparative Economics 37 (1):169-193.

Eagly, Alice H., Steven J. Karau, and Mona G. Makhijani. 1995. "Gender and the effectiveness of leaders: A meta-analysis." Psychological Bulletin 117 (1):125-145.

Eckel, Catherine C. and Philip J. Grossman. 2008. "Men, Women and Risk Aversion: Experimental Evidence." In Handbook of Experimental Economics Results, vol. 1, edited by Charles R. Plott and Vernon L. Smith. Amsterdam: North-Holland, 1061-1073.

Farvaque, Étienne, Hakim Hammadou, and Piotr Stanek. 2009. "Select your Committee: The Impact of Central Bankers Background on Inflation." Economie Internationale $117(1): 99-129$.

_ 2011. "Selecting Your Inflation Targeters: Background and Performance of Monetary Policy Committee Members." German Economic Review 12 (2):223-238.

Feld, Lars P. and Christoph A. Schaltegger. 2010. "Political stability and fiscal policy: Time series evidence for the Swiss federal level since 1849." Public Choice 144 (3):505534.

Foschi, Martha. 2000. "Double Standards for Competence: Theory and Research." Annual Review of Sociology 26 (1):21-42.

Freier, Ronny. 2011. "Incumbency as the Major Advantage: The Electoral Advantage for Parties of Incumbent Mayors." DIW Discussion Paper 1147. 
Frey, Bruno S. 2000. "Was bewirkt die Volkswirtschaftslehre?" Perspektiven der Wirtschaftspolitik 1 (1):5-33.

Galasso, Vincenzo and Tommaso Nannicini. 2011. "Competing on Good Politicians." American Political Science Review 105 (1):79-99.

Galli, Emma and Stefania P. S. Rossi. 2002. "Political Budget Cycles: The Case of the Western German Länder." Public Choice 110 (3):283-303.

Gehlbach, Scott, Konstantin Sonin, and Ekaterina Zhuravskaya. 2010. "Businessman Candidates." American Journal of Political Science 54 (3):718-736.

Göhlmann, Silja and Roland Vaubel. 2007. "The educational and occupational background of central bankers and its effect on inflation: An empirical analysis." European Economic Review 51 (4):925-941.

Haan, Jakob de, Jan-Egbert Sturm, and Geert Beekhuis. 1999. "The Weak Government Thesis: Some New Evidence." Public Choice 101 (3):163-176.

Hagen, Jürgen von and Ian J. Harden. 1995. "Budget processes and commitment to fiscal discipline." European Economic Review 39 (3-4):771-779.

Hallerberg, Mark and Jürgen von Hagen. 1999. "Electoral institutions, cabinet negotiations, and budget deficits within the European Union." In Fiscal institutions and fiscal performance, edited by James M. Poterba and Jürgen von Hagen. Chicago: University of Chicago Press, 209-232.

Hallerberg, Mark, Rolf Strauch, and Jürgen von Hagen. 2007. "The design of fiscal rules and forms of governance in European Union countries." European Journal of Political Economy 23 (2):338-359.

Hau, Harald and Marcel Thum. 2009. "Subprime crisis and board (in-) competence: private versus public banks in Germany." Economic Policy 24 (60):701-752.

Hayo, Bernd and Stefan Voigt. 2011. "Endogenous constitutions: Politics and politicians matter, economic outcomes don't." Journal of Economic Behavior \& Organization (in press).

Hibbs, Douglas A. Jr. 1977. "Political Parties and Macroeconomic Policy." The American Political Science Review 71 (4):1467-1487.

Jochimsen, Beate and Robert Nuscheler. 2011. "The political economy of the German Länder deficits: weak governments meet strong finance ministers." Applied Economics 43 (19):2399-2415.

Johnson, Johnnie E.V. and Philip L. Powell. 1994. "Decision Making, Risk and Gender: Are Managers Different?" British Journal of Management 5 (2):123-138.

Johnson, W. Bruce, Robert P. Magee, Nandu J. Nagarajan, and Harry A. Newman. 1985. "An analysis of the stock price reaction to sudden executive deaths Implications for the managerial labor market." Journal of Accounting and Economics 7 (1-3):151-174. 
Jones, Benjamin F. and Benjamin A. Olken. 2005. "Do Leaders Matter? National Leadership and Growth Since World War II." The Quarterly Journal of Economics $120(3): 835-864$.

. 2009. "Hit or Miss? The Effect of Assassinations on Institutions and War." American Economic Journal: Macroeconomics 1 (2):55-87.

Judson, Ruth A. and Ann L. Owen. 1999. "Estimating dynamic panel data models: a guide for macroeconomists." Economics Letters 65 (1):9-15.

Kirschen, Étienne S., Jean Benard, Hans Besters, Frank Thomas Blackaby, Otto Eckstein, Just Faaland, Floor Hartog, Lucien Morissens, and Emanuele Tosco. 1964. Economic policy in our time: Vol. 1. General theory. Amsterdam: North-Holland.

Kiviet, Jan F. 1995. "On bias, inconsistency, and efficiency of various estimators in dynamic panel data models." Journal of Econometrics 68 (1):53-78.

. 1999. "Expectations of expansions for estimators in a dynamic panel data model; some results for weakly exogenous regressors." In Analysis of panels and limited dependent variable models, edited by Cheng Hsiao, Kajal Lahiri, Lung-Fei Lee, and M. Hashem Pesaran. Cambridge: Cambridge University Press, 199-225.

Kiviet, Jan F. and Maurice J. G. Bun. 2001. "The accuracy of inference in small samples of dynamic panel data models." Tinbergen Institute Discussion Paper 006/4.

Kontopoulos, Yianos and Roberto Perotti. 1999. "Government Fragmentation and Fiscal Policy Outcomes: Evidence from OECD Countries." In Fiscal institutions and fiscal performance, edited by James M. Poterba and Jürgen von Hagen. Chicago: University of Chicago Press, 81-102.

Lott, John R. and W. Robert Reed. 1989. "Shirking and sorting in a political market with finite-lived politicians." Public Choice 61 (1):75-96.

Lyness, Karen S. and Madeline E. Heilman. 2006. "When Fit Is Fundamental: Performance Evaluations and Promotions of Upper-Level Female and Male Managers." Journal of Applied Psychology 91 (4):777-785.

McKay, Joanna. 2004. "Women in German Politics: Still Jobs for the Boys?" German Politics 13 (1):56-80.

Nickell, Stephen. 1981. "Biases in Dynamic Models with Fixed Effects." Econometrica 49 (6):1417-1426.

Paola, Maria de and Vincenzo Scoppa. 2011. "Political competition and politician quality: Evidence from Italian municipalities." Public Choice 148 (3-4):547-559.

Perotti, Roberto and Yianos Kontopoulos. 2002. "Fragmented fiscal policy." Journal of Public Economics 86 (2):191-222.

Persson, Petra and Ekaterina Zhuravskaya. 2011. "Elite Capture in the Absence of Democracy: Evidence from Backgrounds of Chinese Provincial Leaders." mimeo . 
Persson, Torsten and Guido Tabellini. 1999. "Political Economics and Macroeconomic Policy." In Handbook of macroeconomics, vol. 1, edited by John B. Taylor and Michael Woodford. North Holland: Elsevier, 1397-1482.

Potrafke, Niklas. 2010. "Public Expenditures on Education and Cultural Affairs in the West German States: Does Government Ideology Influence the Budget Composition?" German Economic Review 12 (1):124-145.

Reskin, Barbara F. and Denise D. Bielby. 2005. "A Sociological Perspective on Gender and Career Outcomes." Journal of Economic Perspectives 19 (1):71-86.

Rogoff, Kenneth. 1990. "Equilibrium Political Budget Cycles." American Economic Review 80 (1):21-36.

Rogoff, Kenneth and Anne Sibert. 1988. "Elections and Macroeconomic Policy Cycles." The Review of Economic Studies 55 (1):1-16.

Roubini, Nouriel and Jeffrey D. Sachs. 1989a. "Government Spending and Budget Deficits in the Industrial Countries." Economic Policy 4 (8):100-132.

- 1989b. "Political and economic determinants of budget deficits in the industrial democracies." European Economic Review 33 (5):903-933.

Schaltegger, Christoph A. and Lars P. Feld. 2009. "Do large cabinets favor large governments? Evidence on the fiscal commons problem for Swiss Cantons." Journal of Public Economics 93 (1-2):35-47.

Schneider, Christina J. 2010. "Fighting with one hand tied behind the back: Political budget cycles in the West German states." Public Choice 142 (1-2):125-150.

Seitz, Helmut. 2000. "Fiscal Policy, Deficits and Politics of Subnational Governments: The Case of the German Laender." Public Choice 102 (3):183-218.

- 2008. "Die Bundesbestimmtheit der Länderausgaben." Wirtschaftsdienst $88(5): 340-348$.

Svaleryd, Helena. 2009. "Women's representation and public spending." European Journal of Political Economy 25 (2):186-198.

Tirole, Jean. 1994. "The Internal Organization of Government." Oxford Economic Papers $46(1): 1-29$.

Volkerink, Bjørn and Jakob de Haan. 2001. "Fragmented Government Effects on Fiscal Policy: New Evidence." Public Choice 109 (3):221-242.

Wehner, Joachim. 2010. "Cabinet structure and fiscal policy outcomes." European Journal of Political Research 49 (5):631-653.

Woo, Jaejoon. 2003. "Economic, political, and institutional determinants of public deficits." Journal of Public Economics 87 (3-4):387-426.

\section{A. Appendix}




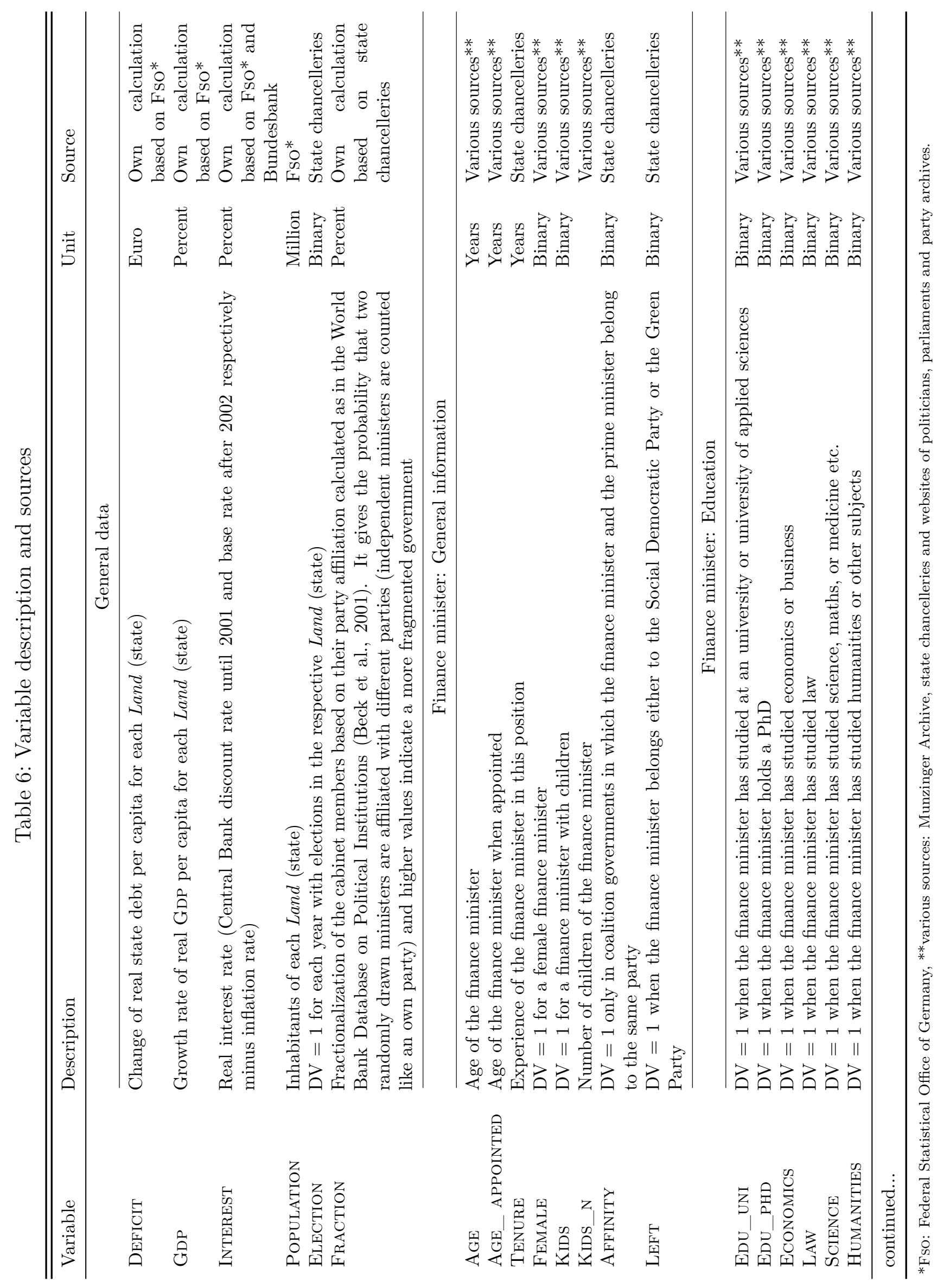




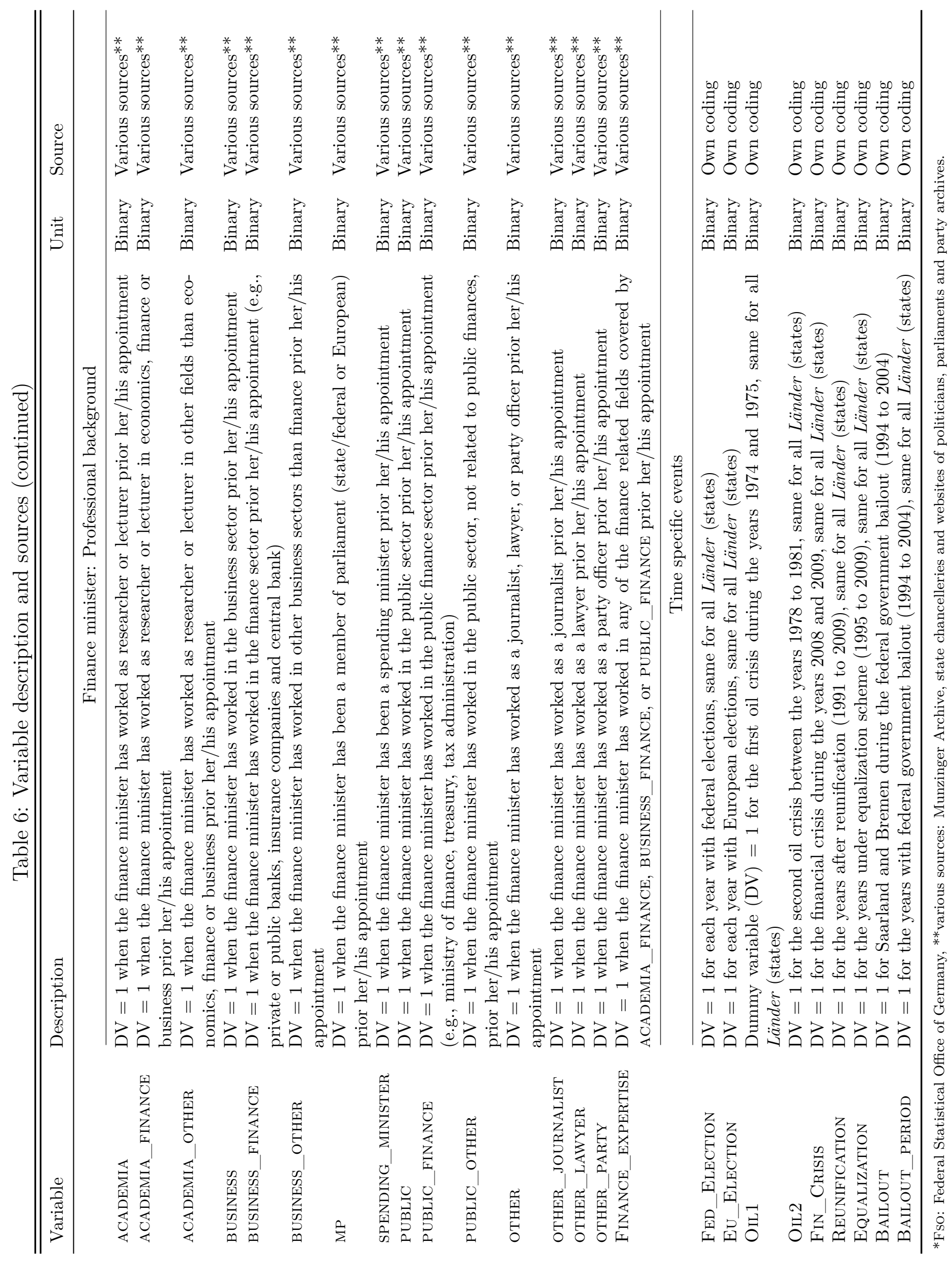

